\title{
Financial Institutions' Business Models and the Global Transmission of Monetary Policy
}

Argimon, Isabel, Clemens Bonner, Ricardo Correa, Patty Duijm, Jon Frost, Jakob de Haan, Leo de Haan, and Viktors Stebunovs

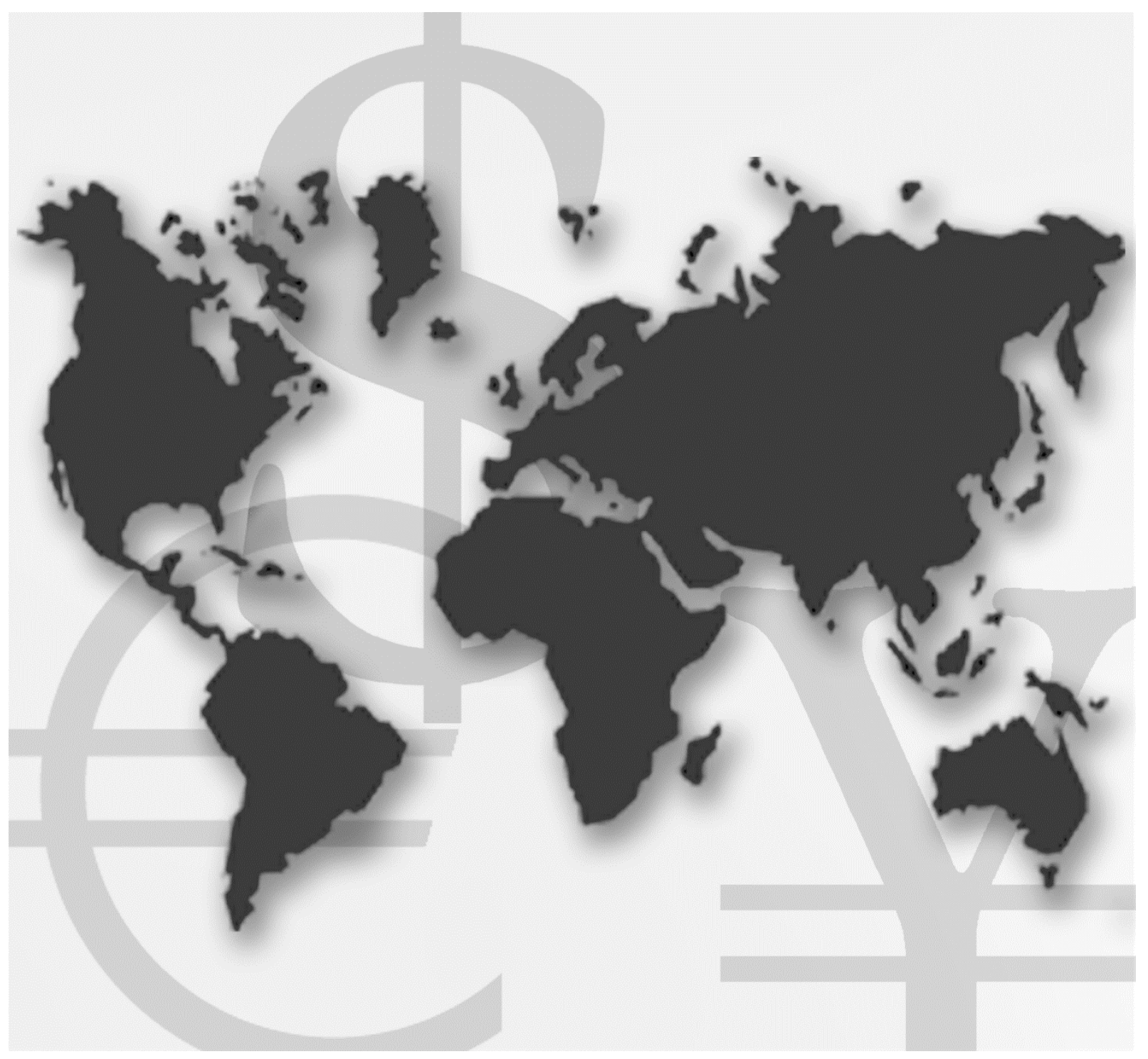

\section{International Finance Discussion Papers}

Board of Governors of the Federal Reserve System 
Board of Governors of the Federal Reserve System

International Finance Discussion Papers

Number 1228

May 2018

\section{Financial Institutions' Business Models and the Global Transmission of Monetary Policy}

Isabel Argimon, Clemens Bonner, Ricardo Correa, Patty Duijm, Jon Frost, Jakob de Haan, Leo de Haan, and Viktors Stebunovs

NOTE: International Finance Discussion Papers are preliminary materials circulated to stimulate discussion and critical comment. References to International Finance Discussion Papers (other than an acknowledgment that the writer has had access to unpublished material) should be cleared with the author or authors. Recent IFDPs are available on the Web at www.federalreserve.gov/pubs/ifdp/. This paper can be downloaded without charge from the Social Science Research Network electronic library at www.ssrn.com. 


\title{
Financial institutions' business models and the global transmission of monetary policy
}

\author{
Isabel Argimon ${ }^{\mathrm{a}}$, Clemens Bonner ${ }^{\mathrm{b}, \mathrm{d}}$, Ricardo Correa ${ }^{\mathrm{c}}$, Patty Duijm ${ }^{\mathrm{b}}$, \\ Jon Frost ${ }^{\mathrm{b}, \mathrm{d}, \mathrm{e}}$, Jakob de Haan ${ }^{\mathrm{b}, \mathrm{f}, \mathrm{g}}$, Leo de Haan $^{\mathrm{b}}$, and Viktors Stebunovs ${ }^{\mathrm{c}}$ \\ ${ }^{a}$ Banco de España \\ ${ }^{\text {e }}$ Financial Stability Board \\ ${ }^{\mathrm{b}}$ De Nederlandsche Bank \\ ${ }^{\mathrm{f}}$ University of Groningen \\ ${ }^{\mathrm{c}}$ Federal Reserve Board \\ g CESifo \\ d VU University Amsterdam
}

May 15, 2018

\begin{abstract}
Global financial institutions play an important role in channeling funds across countries and, therefore, transmitting monetary policy from one country to another. In this paper, we study whether such international transmission depends on financial institutions' business models. In particular, we use Dutch, Spanish, and U.S. confidential supervisory data to test whether the transmission operates differently through banks, insurance companies, and pension funds. We find marked heterogeneity in the transmission of monetary policy across the three types of institutions, across the three banking systems, and across banks within each banking system. While insurance companies and pension funds do not transmit home-country monetary policy internationally, banks do, with the direction and strength of the transmission determined by their business models and balance sheet characteristics.
\end{abstract}

JEL classification: E5, F3, F4, G2.

Keywords: monetary policy transmission, global financial institutions, bank lending channel, portfolio channel, business models.

\footnotetext{
* We would like to thank Greg Cohen and Nathan Mislang for their excellent assistance and collaboration in this project. We also want to thank our discussant Olena Havrylchyk, participants at the conference on "Global Financial Linkages and Monetary Policy Transmission” hosted by the Banque de France, two anonymous referees and the editors of this special issue for their valuable comments. The views expressed in this paper are solely those of the authors and should not be interpreted as reflecting the views of Banco de España, the Board of Governors of the Federal Reserve System, De Nederlandsche Bank, or the Financial Stability Board.
} 


\section{Introduction}

Financial institutions play an important role in the transmission of monetary policy to the real economy. As these institutions have increased their global scope, their role as conduits in the transmission of monetary policy across borders has become a significant concern. In this paper, we use confidential supervisory information to study the relation between such international transmission and global financial institutions’ business models. Specifically, we examine whether banks headquartered in the Netherlands, Spain, and the United States transmit their home country's monetary policy differently to other countries and whether these banks transmit monetary policy differently compared to insurance companies and pensions funds headquartered in the Netherlands.

Having data for banks from these three structurally diverse countries and for insurance companies and pension funds in the Netherlands gives us a unique perspective on the role of business models in the international transmission of monetary policy across three dimensions.

First, we compare banks across the three countries. As noted by the Committee on the Global Financial System (2010), banks headquartered in different countries typically use a diverse array of models to organize their international operations. The three countries covered in our study represent close to the full spectrum of alternatives. On the one extreme, Spanish banks tend to rely on subsidiaries that both lend and obtain the bulk of funding in the host countries, with only limited funding sourced from their head offices. We label such banks as "decentralized.” On the other extreme, U.S. banks tend to cater to their international clients from their head offices and manage liquidity internally across their organizations. We label such banks as "centralized”. Dutch banks have moved towards a model that is somewhere in between the two extremes.

Second, we compare banks within each country. While banks in each country generally follow a similar model, there are still notable differences among them. For example, some banks are larger and have more regulatory capital than others. We exploit such variation to study particular channels of monetary policy transmission. The primary channel of transmission described in the literature is the bank lending channel (Bernanke and Gertler, 1995), which analyzes the effects of monetary policy on bank lending as a result of constraints on banks' funding. We associate this channel with size, as larger banks have lower external financing frictions. Another channel of 
transmission is the portfolio channel, which suggests that banks, depending on their balance sheet characteristics, rebalance their portfolios of loans and securities in response to changes in monetary policy. We associate this channel with the level of bank capitalization, as banks with lower capital may have to readjust their portfolios towards safer assets as monetary policy tightens.

In addition, we also exploit differences across banks in a given country in the degree of decentralization of their foreign activities. For example, while Spanish banks generally follow a decentralized business model, some of them are more decentralized than others. We use bankspecific time-varying decentralization indicators to study whether monetary policy in a home country affects the foreign operations of decentralized banks to a smaller extent than those of centralized banks.

Third, for the Netherlands, we compare banks to non-bank financial intermediaries-insurance companies and pension funds. In particular, we explore whether insurance companies and pension funds adjust their foreign claims in response to monetary policy changes at home, and whether their responses are comparable to those of banks. While both banks and these non-bank financial institutions conduct sizeable foreign activities, they have drastically different business models as evident in their balance sheets. For example, while banks and insurance companies hold loans and short- and long-term fixed income securities, banks rely on deposits, wholesale funding, and central bank liquidity to finance themselves, but insurance companies do not. Therefore, these types of institutions may transmit the euro-area monetary policy differently to other countries.

We analyze banks' foreign activities using supervisory data for financial institutions headquartered in the three countries. These bank-specific data are collected by the prudential supervisor of the corresponding country—Banco de España (BdE), De Nederlandsche Bank (DNB), and the Federal Reserve. These data include foreign claims, broken down by counterparty sector (banks, private non-banks, and public sector) and type of claims (crossborder and local affiliates' claims). Country aggregates of these bank-level data are reported to the Bank for International Settlements (BIS) for the International Banking Statistics. We limit our analysis to the period 2000:Q1 to 2014:Q4 for Spanish banks and up to 2015:Q4 for Dutch and U.S. banks. Due to the confidential nature of the data, the bank-specific information from the 
different reporting countries cannot be combined. Thus, our empirical tests rely on estimating the same specifications for each country separately.

We study insurance companies and pension funds' foreign activities using data for the Netherlands. Similar data for the other countries are not available. Information on the foreign claims held by these financial institutions is reported as part of the balance of payments statistics, which contain details on the holdings of assets split by country of origin and sector at the individual-institution level. The data are available at a quarterly frequency between 2006:Q1 and 2015:Q4. We match the variable definitions for these financial institutions to those used for banks.

While comparing banks across and within countries, we get a rich and nuanced set of results. We find that there is heterogeneity among banks headquartered in different countries, which is driven by differences in business models of foreign operations. U.S. banks, which follow a more centralized model, consistently adjust their foreign claims as a result of domestic monetary policy changes. In contrast, we do not find a consistent direct effect of monetary policy on Dutch and Spanish banks' foreign operations. However, these unconditional results are potentially subject to criticism, as monetary policy may be endogenously determined in this simple empirical setting. Thus, we follow the empirical banking literature on the transmission of monetary policy by identifying the effect of policy rate changes on banks' claims by using information on banks’ funding and asset holdings characteristics within a country.

For the bank lending channel, we show that larger banks are better able to mitigate the negative effects of contractionary monetary policies than smaller banks. This result is stronger for crossborder claims, which are directly funded from the parent's balance sheet, than for local claims, which can be funded by resources sourced at the local offices. Although the results for the interaction between monetary policy and bank size are consistent across the three banking sectors, the total effect of monetary policy for the median bank across the three countries is different. While the median-sized bank in the Netherlands and Spain does not significantly change its cross-border claims as home monetary policy tightens, the median bank in the U.S. increases those claims. However, the result for U.S. banks is not economically important, as a 100 basis points increase in the U.S. policy rate leads to a 3.2 percentage point increase in the growth rate of cross-border claims for the median bank, slightly more than a tenth of a standard 
deviation for this variable.

As for the portfolio channel, asset composition may matter only for Dutch and U.S. banks, which respond differently depending on their capitalization levels. We find that better capitalized Dutch and U.S. banks tend to change their international exposures by less as policy rates increase, especially their cross-border claims. This result may be driven by the limited capacity of less capitalized banks to lend domestically as monetary conditions tighten.

We also find that in response to a tightening at home, Dutch and Spanish banks with more decentralized operations increase their cross-border claims. But only Spanish banks with more decentralized operations boost their total foreign claims. This may reflect global banks' attempt to reposition their market shares as domestic monetary policy changes. As noted before, U.S. banks increase their foreign claims, regardless of their business model, as monetary policy tightens. These results suggest that there is slightly more heterogeneity in the reaction of banks with different business models in the Netherland and Spain, compared to U.S. banks.

While comparing banks and non-bank financial intermediaries, we find that, unlike banks, insurance companies and pension funds in the Netherlands do not increase their foreign claims in response to a monetary policy tightening at home.

Our paper contributes to a growing literature on the international transmission of monetary policy through financial institutions. For example, Temesvary et al. (2018) find evidence that monetary easing by the Federal Reserve is associated with greater lending by U.S. banks abroad, which they attribute to the bank lending channel, whereby especially liquidity-constrained banks are able to use central bank liquidity to fund new loans. For a larger country sample, Bruno and Shin (2015) use a VAR framework to show that a contractionary U.S. monetary policy shock leads to a decrease of cross-border lending and of leverage of international banks. Bremus and Fratzscher (2015) report that expansionary monetary policy since the crisis has supported crossborder lending, both inside and outside the euro area, while tighter regulation has constrained such lending. Conversely, Correa et al. (2018) find evidence that a tighter monetary policy stance is associated with slower credit growth at home and faster lending growth abroad. They explain this with an "international portfolio rebalancing channel," by which banks substitute domestic lending for foreign when high domestic rates push down collateral values for domestic 
borrowers, encouraging lending abroad. Our evidence, especially for the portfolio channel regressions, is more consistent with the results of Correa et al. (2018) than those of the other studies.

Our contribution to this literature is threefold. First, the bank-level structure of our data allows us to better identify the effects of monetary policy on the foreign claims of banks. Second, and more importantly, our focus on the importance of business models in the transmission of monetary policy is novel. Our results provide new insights for both academics and policy makers. Third, the use of information for banks and non-bank financial institutions with different business models across countries allows us to assess the external validity of our results compared to studies that focus only on information from one country and one segment of the financial sector.

The rest of the paper is structured as follows. Section 2 discusses financial intermediaries' internationalization strategies. Section 3 describes the methodology and section 4 the data. Section 5 covers the results of our tests for banks that are headquartered in the Netherlands, Spain, and the United States, and insurers and pension funds that are headquartered in the Netherlands. Lastly, section 6 concludes.

\section{A narrative of financial intermediaries' internationalization strategies}

The narrative of banks' internationalization strategies discussed in this section breaks down the models for conducting foreign activities into four dimensions: the importance of foreign activities, the method of organization of foreign activities, the choice of host countries, and the choice of a market niche. Although, choices along these dimensions are not independent—for example, choosing to compete in a retail market in a given host country implies establishing a local office - these choices are mostly predetermined from the point of view of our empirical analysis. While insurance companies and pension funds may have other reasons than banks to expand abroad, these non-bank intermediaries likely have to make decisions along similar dimensions. In the remainder of the section, we explain why we classify Spanish and U.S. banks as having generally opposite internationalization strategies, with Dutch banks falling in between.

The importance of foreign activities for the Dutch, Spanish, and U.S. banking systems varies greatly, with foreign activities being the most important for Dutch and Spanish banks and the least important for U.S. banks. According to the BIS International Banking Statistics (as of 
2017:Q3), foreign claims account for about 50 percent of Dutch banks' total assets, about 45 percent of Spanish banks' total assets, and about 20 percent of U.S. banks' total assets. ${ }^{2}$ The importance of these activities differs for various reasons, with the size of the home market and the capacity to generate earnings there likely being key. For example, the U.S. market for banking services is very large; it is not considered to be oversaturated; and it allows U.S. banks to maintain returns on assets at a high level. Note that the importance of foreign activities for banks within a given banking system may vary too: some banks allocate a lot of balance sheet space to such activities, some allocate very little. ${ }^{3}$

The organizational structure to conduct foreign activities varies across the Dutch, Spanish, and U.S. banking systems. On the one extreme, Spanish banks tend to rely on subsidiaries that both lend and obtain funding locally. The bulk of Spanish banks' funding is in form of deposits that are denominated in local currencies. Their capital and liquidity are located and managed directly in the host countries, and, thus, are subject to the host country's regulation and supervision. The choice of this structure reflects the expertise of Spanish banks in retail services and products; the principles of their home supervisors which include financial autonomy for foreign operations; and, in the case of the expansion into Latin America, the principles of the host supervisors (Cortina and Fernández de Lis, 2016). Consistently, the Spanish banking system tends to have percentage-wise much more local claims than cross border claims. On the other extreme, U.S. banks tend to conduct foreign operations from their head offices and manage liquidity internally across their organizations. Dutch banks moved towards a model that is somewhere in between the two extremes. Currently, half of their foreign activities comes from their local offices and the other half from the headquarters (De Nederlandsche Bank, 2015).

The choices of host or counterparty countries are also different across the three banking sectors. Besides the United Kingdom and the United States, Spanish banks primarily concentrate their foreign activities on Latin America, in part, because of common language and cultural similarities. While Dutch banks have a global footprint, they tend to concentrate on EU markets

\footnotetext{
${ }^{2}$ Comparing the contributions of foreign activities to net income is another way of establishing the importance, but such data are not consistently available at a banking system level.

${ }^{3}$ In fact, the ratio of foreign claims to total assets averaged across banks in a given system is much lower than the ratio of foreign claims to total assets for the given system.
} 
(de Haan et al., 2015). ${ }^{4}$ Large U.S. banks tend to focus on financial centers, while there is not a clear pattern in the foreign activities of smaller U.S. banks. Among large U.S. banks, however, Citigroup, an institution founded as the City bank of New York in 1812, breaks the mold for historical reasons. Well before global banking was a phenomenon in the early $20^{\text {th }}$ century, the bank had dozens of local offices across the world (Rugman, 2009), including a branch in China.

The choices of market niches also differ. Spanish banks, given their domestic expertise in retail banking and to follow supervisory guidance, specialize in the provision of retail services in their host countries. The choice of this market niche obviously necessitates operating out of "brickand-mortar” local offices. In contrast, U.S. banks tend to cater to international clients, both financial and nonfinancial corporates. Over the past decades, U.S. banks used their competences in the creation and provision of sophisticated corporate services and products to proactively sell them to foreign customers (Venzin, 2009). Larger U.S. banks do not need a large number of local offices to provide these service and products; they conduct their foreign activities out of the headquarters or out of their local offices in financial centers. As for the Dutch banking system, half of the system's foreign activities comes from their local offices and the other half from the headquarters. There is not necessarily a clear pattern in the system's cross-border or local office claims (De Nederlandsche Bank, 2015).

Figure 1, summarizes the business models of these banking sectors, described above, along two dimensions (Committee on the Global Financial System, 2010). The first dimension is related to banks’ management of liquidity across their global offices. Banks that conduct a substantial amount of intragroup funding are classified as centralized. The second dimension is related to the degree of local intermediation conducted by global banks. Banks that perform most of their global operations through cross-border lending follow a more centralized approach, while decentralized banks use subsidiaries or branches (together labelled local affiliates) to conduct their foreign activities. ${ }^{5}$ Such a distinction is similar to the approach followed in McCauley et al. (2010) to classify global banks into multinational and international banks.

\footnotetext{
${ }^{4}$ Dutch banks are also active across North American, Asian, and Latin American markets.

${ }^{5}$ Subsidiaries are local banks owned by the parent company, which generally fall under the supervision of the host supervisory authority and are subject to local capital requirements. Branches are foreign offices, which are generally supervised by the home authority, and are subject only to local liquidity requirements.
} 
The figure reports measures of intragroup funding and local intermediation for Dutch, Spanish, and U.S. banks at four points in time: 2000:Q4, 2005:Q4, 2010:Q4, and 2015:Q4. At these four points in time, it is clear that the banking sectors of the Netherlands (NL), Spain (ES), and the United States (US) follow different business models to conduct their foreign activities. Consistent with the narrative described before, Spanish banks mostly located in the lower-right quadrant, with low intragroup funding and high local intermediation, while the U.S. banks are mostly located in the upper left quadrant, with low local intermediation and high intragroup funding. The Dutch banking sector mostly falls in between. These differences in business models may help us explain the reaction of banks located in these countries to monetary policy.

Lastly, there are three key differences between the general business models of banks on the one hand, and insurance companies and pension funds on the other. First, the institutional framework for these entities is different, as banks have access to central bank liquidity while insurers and pension funds typically do not. Second, banks have long-term assets and short-term liabilities, while this maturity mismatch is generally reversed for insurers and pension funds, whose risk are mostly on the liabilities side (Paulson et al., 2014). Third, the type of lending is different: banks have a large share of retail lending (for example, mortgages, small and medium enterprise loans, and so on) while insurers and pension funds are more likely to buy bonds and other capital market securities.

Insurance companies and pension funds may also have other reasons than banks to expand abroad, but these non-bank intermediaries likely have to make decisions along the same dimensions. ${ }^{6}$ The investment portfolios of non-bank intermediaries are internationally oriented as these are held to diversify the country-specific risks. As buying securities in the international financial markets does not require operating local offices, they are carried out of non-bank intermediaries' headquarters.

\footnotetext{
${ }^{6}$ However, due to the current low interest rate environment and in a search for yield, Dutch insurance companies and pension funds (albeit the latter to a lesser extent) significantly increased their mortgage lending activities in the past 10 years. These activities are however mainly focused on the domestic mortgage market.
} 


\section{Empirical methodology}

The main focus of the empirical strategy is to identify the effect of monetary policy on financial institutions' foreign claims - cross-border and, separately, local claims - conditional on their business models. The methodology is broadly based on the framework discussed in Buch et al. (2018). First, we analyze how monetary policy affects banks that are headquartered in countries that are characterized by banking sectors operating diverse business models (the Netherlands, Spain, and the United States). Second, we explicitly test how monetary policy affects banks with different internationalization models within these same countries. In particular, we compare banks that rely on their branches and foreign subsidiaries for foreign activities (a decentralized model) with those that conduct their foreign operations mostly out of their head offices (a centralized model). Lastly, we study whether insurance and pension funds react differently to monetary policy than banks.

\subsection{Transmission channels of monetary policy}

The literature on the transmission of monetary policy through banks has traditionally focused on two channels: the bank lending channel and the portfolio channel. The bank lending channel (Bernanke and Gertler, 1995) emphasizes the role of bank liabilities in the transmission of monetary policy. That is, as policy rates increase the cost of banks' external financing also rises, which may lead to a decrease in lending. In contrast, the portfolio channel focuses on the effect of monetary policy changes on the composition of banks' assets (Den Haan et al., 2007; Dell'Ariccia et al., 2017; Jimenez et al., 2014). As policy rates increase, banks may seek to rebalance their portfolios to safer assets, with the opposite happening as policy rates decrease.

This first specification intends to capture the relation between domestic monetary policy and the growth rate in foreign claims for each bank. Formally, we estimate the following equation:

$$
\begin{aligned}
\Delta Y_{b, j, t}= & \alpha_{0}+\sum_{k=0}^{K}\left(\alpha_{1, k} \Delta M P_{t-k}^{\text {domestic }}+\alpha_{2, k} \Delta M P_{t-k}^{\text {domestic }} \cdot \text { Friction }_{b, t-K-1}\right)+\alpha_{3} \text { Friction }_{b, t-K-1} \\
& +\alpha_{4} X_{b, t-1}+\alpha_{5} Z_{t-1}^{\text {domestic }}+\alpha_{6} Z_{j, t-1}+\alpha_{7} V I X_{t-1}+f_{j}+f_{b}+\varepsilon_{b, j, t}
\end{aligned}
$$

where $\Delta Y$ is the log change of foreign claims of bank $b$ on country $j$ at time $t$; we use claims on foreign non-bank private borrowers, distinguishing between cross-border claims and claims 
booked at the foreign affiliates of these banks (henceforth named "local claims"). ${ }^{7}$ For the Netherlands and Spain, foreign claims are on residents of non-euro-area countries. ${ }^{8}$

Monetary policy is captured by $\triangle M P^{\text {domestic }}$, which is either the first difference of the nominal policy rate or the shadow rate for the domicile country of a given bank (from Krippner, 2013). ${ }^{9}$ For Dutch and Spanish banks, these rates are for the euro area. Although during most of the period under consideration monetary policy was loosened, there were also periods when policy became more restrictive. For instance, there is a monetary tightening cycle just prior to the Global Financial Crisis (GFC). The coefficients $\alpha_{1 k}$ and their annual cumulative effect captured by $\Sigma \alpha_{1 \mathrm{k}}$ allow us to test the overall relationship between the change in foreign claims and monetary policy. However, it does not provide information on the specific frictions through which monetary policy affects the international activities of global banks. This direct relation may also be weakly identified, as credit demand factors are difficult to control for.

As summarized in Table 1, we expect that the direct effect of a monetary policy tighteningcaptured by $\Sigma \alpha_{1 \mathrm{k}}$-is negative for both cross-border and local office claims. Moreover, crossborder claims should react more to home-country monetary policy changes compared to local claims. While the former claims are funded with the parent's balance sheet, which is more affected by home-country monetary policy, the latter is likely to be funded with host-country deposits, which are more dependent on the host-country's monetary policy.

To better identify the channels of monetary policy transmission, we use the technique introduced by Kashyap and Stein (2000) and later applied by Cetorelli and Goldberg (2012) to the international context. We introduce a set of regressors labeled Friction. These variables allow us

\footnotetext{
${ }^{7}$ This type of estimation only captures the effect of monetary policy on the intensive margin. Banks' decision to enter or exit from specific countries are not explained by our framework. Alternative estimations, not shown but available on request, use the claims on all sectors.

${ }^{8}$ We exclude Dutch and Spanish banks' claims on euro-area countries because of their high degree of economic integration within the currency union.

${ }^{9}$ As pointed out by Claus et al. (2016), the shadow short rate is a synthetic summary measure that is derived from yield curve data and essentially reflects the degree to which intermediate and longer maturity interest rates are lower than would be expected if a zero policy rate prevailed in the absence of unconventional policy measures. This measure is better at capturing the effect of monetary policy on financial institutions' assets, especially in the effective lower bound (ELB) period. As policy rates reached the ELB, the value of longer dates assets may have changed, as several central banks started their quantitative easing programs. The shadow rate incorporates this information. Further analysis comparing the shadow rate and the slope of the yield curve (available on request) suggests that the shadow rate is more reflective of the monetary policy stance than the slope of the yield curve.
} 
to identify the effect of monetary policy in the cross-section of banks, which mitigates some of the concerns related to the potentially endogenous determination of monetary policy. In the specification, the coefficients of interest are the $\alpha_{2}$, which capture the differential effect of monetary policy on foreign claims, conditional on these frictions.

We include a vector of bank controls $(X)$ in specification (1) and a set of domestic financial and macroeconomic controls ( $Z^{\text {domestic }}$ ), which allows us to take into account changes in domestic credit demand. In addition, we include controls for destination-country credit demand $(Z)$ and global factors (VIX), which may affect changes in the pace of growth of foreign claims. All regressions include destination-country fixed effects and bank fixed effects. Standard errors are clustered at the bank level.

\subsubsection{Banks’ foreign activities and the bank lending channel}

We first test for the significance of the bank lending channel. We use bank size, measured by the log of total assets, as the main regressor that allows us to identify funding frictions across banks. ${ }^{10}$ Larger banks may be able to fund themselves at cheaper rates and withstand changes in monetary policy (Kashyap and Stein, 2000). ${ }^{11}$ As Table 1 notes, we expect that the effect of monetary policy conditional on bank size is positive for both cross-border and local office claims: foreign activities of larger banks are more insulated from monetary policy. Kashyap and Stein (2000) and Cetorelli and Goldberg (2012) have shown that large financial institutions should not be affected by monetary policy changes, as they have better access to external sources of finance or can use their internal liquidity management to mitigate the effect of policy rate changes. We expect that the total effect - the sum of the direct and conditional effects of monetary policy—for banks of the median size should be a wash.

In these bank lending channel regressions, we use the nominal policy rate as our measure of monetary policy. For the euro area, this is the European Central Bank (ECB) main refinancing rate. For the United States, we use the effective federal funds rate, which may vary across days

\footnotetext{
${ }^{10}$ Results with other frictions used in the literature, such as the short-term funding ratio and the liquid assets ratio, can be found in the online appendix.

${ }^{11}$ We caution though that the size may have an alternative interpretation. In the presence of fixed costs of conducting foreign activities, the size may indicate a bank's ability to carry out such activities rather than necessarily access funding markets. Given that our sample consist of bank that already conduct these international activities, we would only be capturing heterogeneous effects within this group.
} 
but it is typically close to the target federal funds rate or within the range set by the Federal Open Market Committee (FOMC). The nominal policy rate is more representative of the cost of funds that banks face. A downside of using this measure is that most of the identification will come from the period before the effective-lower-bound (ELB) was reached, as there is very little variation in the policy rate during the ELB period. ${ }^{12}$

\subsubsection{Banks’ foreign activities and the portfolio channel}

We also identify the portfolio channel using the specification in (1). However, we focus on frictions that may affect the asset side of banks' balance sheets. In particular, the level of a bank's capital financing may determine the amounts and types of assets that the bank can purchase. More capital may allow the banks to invest in potentially riskier assets such as loans to the non-bank private sector. ${ }^{13}$

As reported in Table 1, we expect that the effect of monetary policy conditional on bank capital is ambiguous. Theory suggests that banks with lower levels of capital should decrease theor overall lending as a result of monetary policy tightening, the so called "bank capital channel” (Van den Heuvel, 2002). However, tighter monetary policy could also lead banks to rebalance their asset portfolios toward safer assets (Jimenez et al., 2014). If foreign claims are considered safer in a tightening environment, we should observe a positive relation between increasing policy rates and changes in foreign claims. Given these two counterbalancing effects, we do not have an ex ante expectation for the sign of the coefficients $\alpha_{22}$. As for the total effect of monetary policy, we expect that the effect of monetary policy on well-capitalized banks is ambiguous.

In the portfolio channel regressions, we use the shadow rate as our measure of monetary policy. The shadow rate incorporates the effect of monetary policy on longer dated rates. These rates are not as important for banks' funding conditions, but they may affect the pricing of securities held in financial institutions balance sheets, as well as the returns on potential investment opportunities. As the shadow rates vary even in the ELB period, the tests on the portfolio channel will be identified with information throughout the entire sample period.

\footnotetext{
${ }^{12}$ We do not estimate differential effects of monetary policy in the post crisis period because of multicollinearity problems.

13 The results with other interactions terms, such as with the ratio of commercial and industrial loans to assets, securities to assets, and total claims on foreign borrowers to assets, are shown in the online appendix.
} 


\subsubsection{Non-banks’ foreign activities and channels}

While, to our knowledge, there is no specific theory that relates these channels to non-bank institutions such as insurance companies and pension funds, we use the same empirical approach to analyze the transmission of monetary policy through these institutions. The frictions considered are the solvency ratio, which measures the ability of insurance companies and pension funds to fund their liabilities and is at least somewhat analogous to banks' Tier 1 leverage; and log total assets, again as a measure of these institutions' size. Using these frictions allows us to directly compare whether the transmission of monetary policy through insurance companies and pensions funds is similar to the transmission through banks.

\subsection{Monetary policy and financial institutions' business models}

As noted earlier, the main focus of the paper is to test for the relevance of banks' business models on the international transmission of home-country monetary policy. In the tests described in this section, we divide banks according to the type of foreign activities in which they participate. Specifically, we compare banks that mostly operate by lending to foreign residents from the head office to those banks that establish affiliates abroad to cater to their foreign clients. We label the first type of banks "centralized," while the second type are labeled "decentralized."

To formally test our hypothesis, we estimate the following equation (business model specification):

$$
\begin{aligned}
\Delta Y_{b, j, t}= & \alpha_{0}+\sum_{k=0}^{K}\left(\alpha_{1, k} \Delta M P_{t-k}^{\text {domestic }}+\alpha_{2, k} \Delta M P_{t-k}^{\text {domestic }} \cdot \text { Decentral }_{b, t-K-1}\right)+\alpha_{3} \text { Decentral }_{b, t-K-1} \\
& +\alpha_{4} X_{b, t-1}+\alpha_{5} Z_{t-1}^{\text {domestic }}+\alpha_{6} Z_{j, t-1}+\alpha_{7} V I X_{t-1}+f_{j}+f_{b}+\varepsilon_{b, j, t}
\end{aligned}
$$

The regressors included are the same as in (1), with the exception of Decentral. This variable is an indicator equal to 1 if a bank's foreign activities are mostly conducted through foreign affiliates, that is, if it provides services to its clients in a decentralized structure. This is defined by a ratio of local claims to total foreign claims that is greater than 50 percent. The indicator is equal to 0 if the bank follows a centralized approach to lend to its clients.

We expect that banks that follow a centralized model are more likely to be affected by domestic monetary policy. In contrast, those that operate mostly through decentralized foreign offices may 
be less sensitive to changes in domestic monetary policy. As noted in Table 1, we expect that monetary policy tightening leads to a reduction in both cross-border and local claims for centralized banks. In contrast, we do not have a prior on the total effect of monetary policy on cross-border claims for decentralized banks and we expect no effect on local claims.

\section{Data}

\subsection{Financial institution data - banks}

The main data used in our analysis are the bank-level claims on foreign residents that are collected to produce the International Banking Statistics published by the BIS. These statistics are published in aggregate form at the banking system rather than at the bank level. ${ }^{14}$

The bank-level confidential quarterly reports are submitted by banks to the prudential supervisor of the corresponding country (the DNB, the BdE, and the Federal Reserve). These supervisory databases include time series data on foreign claims, broken down by counterparty sector (banks, public, and non-bank private) and type of lending (cross-border and lending by local affiliates, distinguishing between claims in local and foreign currency).

We merge this information on bank-level foreign claims with quarterly balance sheet reports submitted by banks to their respective supervisors. In particular, for Dutch and Spanish banks, we use confidential balance sheet data provided by these banks to the DNB and BdE, at a consolidated banking group level. Balance sheet, income statement, and selected off-balance sheet data for U.S. commercial banks are drawn from the Federal Financial Institutions Examinations Council (FFIEC) 031 form, better known as the Call Report. The income statement, balance sheet, and selected off-balance sheet data on U.S. bank holding companies are drawn from the FR Y-9C form. ${ }^{15}$

As noted in Section 3, we focus on cross-border and local claims of banks on non-bank private

\footnotetext{
${ }^{14}$ The U.S. regulators release a subset of these data publically. The FFIEC 009 form on the international exposures of U.S. reporting banks is the source of detailed information on the geographic distribution of U.S. bank claims on foreign residents. Although much of the bank-level data are publicly available, some of the bank-level data from the FFIEC 009 report are confidential.

${ }^{15}$ Most of the data collected on the FR Y-9C and FFIEC 031 are available to the public through the Federal Reserve Bank of Chicago's website and the FFIEC Central Data Repository's Public Data Distribution site. There are a small number of series that are confidential. Some bank-level information similar to that reported in the FFIEC 009 is made public in the E.16 Country Exposure Information Report.
} 
borrowers, which include both credit and securities issued by the private sector, including nonbank financial institutions. For Dutch and Spanish banks, we use claims on non-euro-area residents.

Our dependent variable is the log change in the stock of foreign claims, adjusted for exchange rate fluctuations. This is akin to having a real measure of banks' foreign flows, cleaned for exchange rate fluctuations. Specifically, we construct the dependent variable as the difference between the natural log of the claims at $t$ and the natural $\log$ of the exchange rate-adjusted outstanding claims at $t-1$.

We follow a sample selection process that is consistent across the datasets of the three countries to exclude or correct for potential reporting errors and noise. In particular, we drop observations if the change in log claims is greater than 1 or less than -1 (thus excluding most major changes due to mergers and acquisitions and other structural breaks). We exclude bank-country observations at time $t$ if only one bank operates in that country. We also drop bank-country observations for which we do not have eight consecutive observations, that is, two full consecutive years of bank activity in a given country. Finally, we drop foreign claims in countries for which we do not have information on their macroeconomic variables, which we need as controls.

The data cover the period 2000:Q1 to 2014:Q4 for Spanish banks and 2000:Q1 to 2015:Q4 for U.S. and Dutch banks. Our final sample consists of 64 Dutch banks, 59 Spanish banks and 60 U.S. banks - all of which do not necessarily have foreign claims at all times. As shown in Table 2 , the average number of active banks in a given country for the same three countries is 20,18 , and 33, respectively. These banks operate in at most 37, 24, and 48 different jurisdictions.

As recorded in Figure 2, we observe that while U.S. and Dutch banks reduced their total foreign claims during the first years of the GFC, Spanish banks increased their stock of claims. ${ }^{16}$ In fact, the foreign activities of the banking sectors of the Netherlands and the United States underwent

\footnotetext{
${ }^{16}$ A change in reporting for Spanish banks took place in the second quarter of 2005, which resulted in new definitions of some reported variables including total assets. While we have a homogeneous series for the assets at the consolidated level, we do not have such homogeneity in the data that captures the activity of subsidiaries abroad and cross-border claims, although the changes are not large. Similarly, a change in the reporting from for Dutch banks in 2004, led to a more comprehensive coverage of foreign claims. These reporting changes are reflected in sharp increase in the series in Figure 2 for these countries.
} 
substantial growth in the early part of the sample period, leading up to a peak in 2007 in the case of the Netherlands. During and since the GFC, Dutch banks have divested foreign assets. This reflects the acquisition and break-up of ABN Amro in 2008 by the Royal Bank of Scotland, Santander and Fortis; the sale of foreign activities of ING as a condition for state support received in 2008; the nationalization of SNS Reaal in 2013; and a broader deleveraging trend brought on by the losses and capital shortfalls exposed by the crisis. In the case of Spanish banks, those which had received state aid implemented restructuring plans, which did not greatly affect foreign activity. Government interventions resulted in mergers and acquisitions and the almost total disappearance of the savings and loans sector, which had not been, in general, internationally active. For U.S. banks, the GFC led to a restructuring of some of the international businesses for the largest institutions. This adjustment in foreign activities did not prevent U.S. banks from increasing their foreign claims, but the implementation of new regulations under Basel III (Berrospide et al., 2017) and weaker foreign economic growth have led to a slight decrease in foreign claims in recent years.

\subsection{Financial institution data - insurance companies and pension funds}

For insurance companies and pension funds, the data on foreign claims by country is collected by DNB as part of the Dutch balance of payment statistics. This reporting contains detailed information on the holdings of assets, split by country of origin and sector, for each institution. The data are available at a quarterly frequency over the period 2006:Q1-2015:Q4. For the purpose of this analysis, we consider two components of foreign claims: loans made to and bonds issued by the private sector in non-euro-area countries. To match the BIS methodology for the bank data, we define the private sector as other insurance companies and pension funds, other financial institutions (excluding banks), households, and non-financial institutions. The set of control variables, including the solvency position, liquid assets, and total assets, are obtained from supervisory reporting to DNB. As shown in Table 2, our sample consists of 21 insurance companies and 28 pension funds. These institutions account (by assets) for over 70 percent of the Dutch insurance sector and nearly 80 percent of the Dutch pension fund sector, respectively. While the insurance and pension fund sectors are smaller than the Dutch banking sector, they are still sizable relative to the country’s GDP (insurers’ and pension funds' investments representing respectively around 80 percent and 190 percent of Dutch GDP). Compared to insurance 
companies, pension funds are larger, lend more to foreign countries and are also active in a larger number of foreign countries.

Figure 3 shows the evolution of the foreign claims of Dutch insurance companies and pension funds on the private sector. For insurance companies, there is a steady increase in foreign claims until 2010, when claims began to decline. Dutch pension funds exhibit a large decrease in foreign holdings earlier, after 2009:Q1. This decline is technical and is attributed to these institutions' shift towards investing in investment funds, which could be domiciled in the Netherlands but hold foreign securities.

\subsection{Financial institutions’ business models}

There are two categories of business models that we cover in this paper: the first distinguishes business models across banking systems and within the banking sector in a country and the second compares the business models of banks with those of insurance companies and pension funds in the Netherlands.

We noted in Section 2, how we categorize the business models of the three banking sectors covered in our analysis. To classify banks within a country, we calculate the ratio of local affiliate claims to total foreign claims for each bank. A bank is classified as following a decentralized model if it has a ratio of local claims to total foreign claims that is greater than 50

percent. The time-series analysis of these ratios shows that they are not cyclical. These ratios are generally constant for banks over multiple years, and appear to reflect changes in longer-term business models rather than short-term, random changes or cyclical patterns.

As noted in Table 2, the number of centralized banks is much larger that the number of decentralized banks in the three jurisdictions, although decentralized banks may be larger.

\subsection{Other variables}

We include four main sets of control variables: individual institution characteristics, home country controls, host country controls, and a measure to capture international liquidity and risk appetite.

As described in Section 3, we use two bank-level indicators to capture the frictions that banks 
may face as monetary policy changes: a measure of size (log total assets) and a measure of leverage (the Tier 1 capital ratio). Table 2 reports the summary statistics for these variables. U.S. banks are larger and finance their operations with capital in a larger proportion than their Dutch and Spanish counterparts.

To control for supply conditions at the home country, we use time-varying macroeconomic variables. We focus on proxies for the business cycle, such as the GDP gap (BIS, 2014), and the financial cycle, captured by the credit-to-GDP gap (Drehmann et al., 2011). To control for host country demand conditions, we also include the business and the financial cycle proxies for the host country, which we accompany with changes in the host country’s monetary policy. Lastly, we use the VIX to control for international market conditions.

Tables A1 through A4 in the appendix provide detailed descriptions of these variables and the sources used to construct them.

\section{Results}

This section describes the results from the specifications used to test our main hypotheses. We first describe the relation between monetary policy and foreign activities through the framework of the bank lending channel, after which we discuss the estimates for the portfolio channel. Lastly, we show the estimation results comparing the reaction of banks to monetary policy conditional on their business model. In all regressions shown, we distinguish between the effects of monetary policy on financial institutions' cross-border and local office loans. In the text, we only report the main results. The online appendix to this paper provides detailed results for the estimated specifications.

\subsection{Bank business models and monetary policy: the bank lending channel}

Table 3 summarizes the main results for our estimates of equation (1). As noted in Section 3, this specification aims to examine whether tighter monetary policy increases the cost of financial institutions' liabilities leading to an adjustment of their lending. If so, their cross-border lending would decrease. However, the effect on local foreign lending would depend on whether the local office is funded by the parent or by financing from the host country; in the latter case local lending would be less affected by monetary policy in the home country. So we expect that banks' 
cross-border claims are more sensitive to monetary policy than local claims. The former are funded in the home country, while the latter could be funded locally. As will be discussed in more detail below, we indeed find that cross-border claims are more sensitive to domestic monetary policy than local claims.

Furthermore, the sensitivity of lending to external financing costs may depend on the business model of the financial institution and on institution-specific characteristics. If business models indeed play a role, we would expect that the relationship between monetary policy and banks' foreign claims would be different for U.S. and Spanish banks, which as noted before, follow different strategies to conduct their foreign operations. Although we indeed find some differences between the reaction of U.S. and Spanish banks to domestic monetary policy measures, there are also some similarities.

The dependent variable in our specifications is either the log changes in cross-border claims on private non-bank borrowers (columns (1)-(3)) or the log changes in local claims to non-bank borrowers (columns (4)-(6)). For Dutch and Spanish banks, the dependent variable is defined as the claims on non-euro-area residents. The specification shown in Table 3 focuses on the interaction of monetary policy with bank size. All regressions include monetary policy, bankspecific controls and (domestic and host) credit-to-GDP and output gap controls, and the VIX, a measure of global risk aversion.

The results for the baseline (no friction) results (not shown in Table 3 but available in the online appendix), suggest a positive and statistically significant effect of a change in the U.S. short-term interest rate on the log changes in cross-border claims over a one-year period and the log changes in local claims. Likewise, for the Netherlands and Spain the coefficient of the ECB's policy rate is positive and significant for banks' local claims. For Spain it is also significant for banks’ cross-border claims. So even though Spanish and U.S. banks follow different business models, their reaction to monetary policy in the baseline specification is similar, that is, they increase their foreign lending in response to higher domestic monetary policy rates.

Next, we turn to the interaction between monetary policy and bank size. It is likely that large banks would be less sensitive to monetary policy as their external funding costs may be less affected when monetary policy tightens. So we expect that the interaction between monetary 
policy and bank size would be positive.

The results for the interaction between monetary policy and bank size, as shown in Table 3, differ across cross-border claims and local claims. For cross-border claims, we find that larger banks are indeed better able to mitigate the negative effects of contractionary monetary policies than smaller banks. In contrast, for local claims, we do not find a significant interaction term between monetary policy and bank size for the countries considered.

The results for the interaction between monetary policy and bank size for cross-border claims are consistent across the three banking sectors. However, the total effect of monetary policy for the median bank across these three countries is different. While the median-sized bank in the Netherlands and Spain does not significantly react, as monetary policy tightens, the median bank in the U.S. significantly increases its cross-border claims. The economic effects for U.S. banks is small. A 100 basis points increase in the policy rate leads to a 3.2 percentage point increase in the growth of cross-border claims to private non-bank borrowers (about a tenth of a standard deviation).

We also show the total results for banks in the $25^{\text {th }}$ and $75^{\text {th }}$ percentile as the results for the median bank may mask different findings for the entire distribution. Our findings suggest that the total effect of Federal Reserve's rate actions on banks' cross-border lending increases with bank size. Likewise, for local lending by Spanish banks, we find significant total effects for banks in the $75^{\text {th }}$ percentile in contrast to the results for the median bank and those in the $25^{\text {th }}$ percentile.

We have also examined the interaction between monetary policy and the liquid assets ratio (see the online appendix). We expect that banks with more liquid assets would be more sensitive to monetary policy changes. However, in the specification for cross-border claims the coefficients on the interaction terms were not significant (the Netherlands) or very small in economic terms (Spain and the United States). We have also analyzed the interaction between monetary policy and the short-term wholesale funding ratio, which only yields significant results for the crossborder claims of U.S. banks and the local claims of Dutch and Spanish banks (the results can be found in the Tables OA1 and OA2 in the online appendix). 


\subsection{Bank business models and monetary policy: the portfolio channel}

Table 4 presents estimation results for equation (1), but focusing on frictions that may affect banks' portfolio of assets as monetary policy changes. For example, in periods with low rates, as a result of loose monetary policy, financial institutions may search for yield by lending to riskier firms or investing in high-yielding assets. As before, the dependent variable in our specifications is either the log changes in cross-border claims ((columns (1)-(3)) or the log changes in local claims on private non-bank borrowers (columns (4)-(6)).

In these tests, the monetary policy measure is the shadow rate (Krippner, 2013). This measure is better at capturing the effect of monetary policy on financial institutions' assets, especially in the ELB period. As policy rates reached the ELB, the value of longer dated assets may have changed, as several central banks started their quantitative easing programs. The shadow rate incorporates this information. As this mechanism may also be relevant for pension funds and insurance companies, we also estimated a variant of equation (1) for these financial institutions in the Netherlands (data for the other countries are not available as discussed in Section 4).

The results for the baseline (no friction) results (not shown), suggest a positive and statistically significant effect of a change in the U.S. shadow rate on the log changes in banks' local claims on private non-bank borrowers, but no significant effect on the log changes in cross-border claims on the same counterparties over a one-year period. For Spanish banks, the coefficient is significant (but only at the 10\%) for cross-border claims. In contrast, the coefficient on the ECB's shadow rate is not significantly different from zero in the regressions for cross-border and local claims of Dutch banks. We also do not find statistically significant effects of changes in the euro-area monetary policy on foreign (non-euro-area) claims of both insurance companies and pension funds in the Netherlands (not shown; for details see the online appendix).

Next, we examine the interaction between monetary policy and the Tier 1 leverage ratio. As domestic monetary policy tightens, banks may invest in safer assets (den Haan et al., 2007), which may be located abroad. As it is not clear ex ante which claims are riskier, the total impact of a monetary policy tightening on foreign claims is ambiguous.

The results for the interaction between monetary policy and the capital ratio, as shown in Table 4, suggest that an increase in the shadow rate for Dutch and Spanish banks is not associated with 
an increase in the growth of local claims for banks with a higher Tier 1 leverage ratio (columns (4)-(6)). In contrast, U.S. banks with higher capital ratios decrease lending at their foreign offices when domestic monetary policy tightens. As depicted in Figure 1, U.S. banks' centralized model allows them to move resources internally across affiliates as circumstances change. Dutch and Spanish banks are less reliant on internal liquidity management. As monetary policy tightens, U.S. banks with more capital may move resources to the parent office to lend domestically even as economic growth slows due to the higher policy rates. In contrast, Dutch and Spanish banks with higher capital may expand lending but at their foreign locations. Indeed, the coefficient on the interaction term between monetary policy and the Tier 1 leverage ratio is positive, although not significant, for Dutch and Spanish banks.

For cross-border claims, the results for the coefficient on the interaction term between monetary policy and the Tier 1 leverage ratio for U.S. banks are the same as those reported for local claims (columns (1)-(3)). However, the relation between the shadow rate and the log change of crossborder claims for Dutch banks is different from the result for local claims. The coefficient on the interaction term between the change in the shadow rate and the Tier 1 leverage ratio is negative and significant, the same result as found for U.S. banks. Banks with stronger capital positions lend less across borders as monetary policy tightens. As noted before, this result can be explained by stronger-capitalized banks' desire to lend less abroad and more domestically, while the weaker-capitalized banks prefer to diversify their portfolio internationally.

For Dutch pension funds and insurance companies, we do not find evidence for a significant interaction between the monetary policy shadow rate and their solvency ratio (which is somewhat analogous to the Tier 1 leverage ratio for banks); details are shown in the online appendix. The different behavior of pension funds and insurance companies can potentially be explained by the different business models of these institutions. In general, insurers and pension funds have a long-term investment horizon, and mainly invest via (long-term) bonds. Thereby they may be less responsive to the short-term changes in monetary policy. Besides, Frost et al. (2018) find that while Dutch insurance companies and pension funds do not respond to monetary policy, they do increase international lending when bank capital requirements in host countries are tightened. This finding indicates that bank regulatory changes may be a stronger driver of insurance and pension funds foreign activities than monetary policy. 
As shown in the online appendix, we have also considered the interaction between the shadow rate and several other bank-specific variables, like the ratio of C\&I loans (which captures whether banks are more lending focused) and the ratio of securities to total assets (which captures the effect of monetary policy on typically mark-to-market securities). However, the Tier 1 leverage ratio is the only balance sheet characteristic that affects banks' response to monetary policy.

Summarizing these results, banks adjust their international portfolios depending on their balance sheet strength. This adjustment is different across banking sectors, with those operating more centralized models being more responsive to monetary policy changes. ${ }^{17}$

\subsection{Bank business models and monetary policy: centralized vs. decentralized models}

Table 5 shows the regression results for non-bank private claims where we take the banks' business models for foreign activities into account, as described in equation (2). The dependent variable differs across columns: change in total claims (columns (1)-(3)), change in local claims (columns (4)-(6)), and the change in cross-border claims (columns (7)-(9)). The measure of monetary policy in these specifications is the change in nominal policy rates.

For the Netherlands and Spain, we find that banks' business models matter in the transmission of home-country monetary policy to cross-border claims. In particular, the interaction term of monetary policy and the decentralized dummy is positive and statistically significant: banks that follow a decentralized model increase their cross-border lending more than those that follow a centralized model in response to a tightening in the euro-area monetary policy. This effect is particularly strong for Spanish banks that follow a decentralized model, but it is also present for total claims for Spanish banks.

The results for U.S. banks contrast with those for Dutch and Spanish banks. The coefficients for the interaction with our decentralization dummy and U.S. monetary policy on total claims on foreign residents, local claims, and cross-border claims are not significant. This suggests that centralized and decentralized U.S. banks do not systematically differ in their foreign lending

\footnotetext{
${ }^{17}$ In response to comments by one referee, we split the sample period before and after 2008Q3. The results in the period prior to the crisis actually explain most of our total findings, which suggests that our results are not driven by the crisis years (results available on request).
} 
behavior.

The total effect is consistent across the three banking systems. The effect is always positive and most often significant, the least so for Dutch banks.

These patterns appear to highlight the differences in the general business models of each banking system. While the Spanish banking system is the most decentralized, the U.S. system is the least decentralized, and the Dutch system falls in between. So, even though some U.S. banks are more decentralized than other U.S. banks, the degree of decentralization of the former is not that high to be important for international transmission.

\section{Conclusions}

The increasing global scope of financial institutions has enhanced the potential transmission of monetary policy changes across borders. In this paper, we use confidential supervisory information for the Netherlands, Spain, and the United States to test whether domestic monetary policy affects the growth of financial institutions’ foreign claims.

The choice of countries in our study is important, as we also assess whether financial institutions with diverse business models react differently to monetary policy. Spanish banks have traditionally used a decentralized business model to cater to their foreign clients, relying on subsidiaries largely funded with deposits sourced in the host country. In contrast, U.S. banks have conducted their global operations in a more centralized structure, moving liquidity across their domestic and foreign offices and providing more credit directly from their head offices. Similarly, we test whether banks with heterogeneous business models within countries exhibit different sensitivities to monetary policy changes. Lastly, we assess whether insurance companies and pension funds in the Netherlands adjust their international exposures similarly to banks in response to monetary policy actions.

Our results show that U.S. banks, which follow a more centralized business model, are more sensitive to domestic monetary policy changes than Dutch and Spanish banks. When we conduct tests to assess the importance of the bank lending channel on these banks, we find that larger U.S. banks increase their foreign exposures as monetary policy tightens. In contrast, monetary policy appears to have a more negative effect on the foreign exposures of the more decentralized Dutch and Spanish banks. 
We also test whether banks react to monetary policy through the portfolio channel. We find that U.S. banks decrease their international exposures as monetary policy tightens, but this is only applicable to institutions with higher capital levels. We find similar differences based on capitalization for the Netherlands for cross-border claims, while Spanish banks do not show any significant differences in their reaction to monetary policy across levels of capitalization.

We further analyze the impact of monetary policy on banks by comparing the reaction of centralized and decentralized institutions to policy rate changes within a country. We find that Dutch and Spanish banks change their international exposures depending on their business models. Decentralized Dutch banks increase their cross-border claims as domestic monetary policy tightens. Similarly, decentralized banks in Spain increase their cross-border and total claims as policy tightens, tilting their portfolios towards foreign claims. It appears that global Spanish banks with foreign affiliates are more willing to increase their cross-border claims as a response to tighter monetary policy, perhaps as a complement to the activities conducted in those foreign offices.

Lastly, we find that insurance companies and pension funds do not change their foreign claims in response to monetary policy changes. 


\section{References}

Bank for International Settlements. 2014. 84th Annual Report, Debt and the financial cycle: domestic and global, Chapter IV, June.

Bernanke, B., Gertler, M., 1995. Inside the black box. Journal of Economic Perspectives, 9(4), 2748.

Berrospide, J., Correa, R., Goldberg, L.S., Niepmann, F., 2017. International banking and crossborder effects of regulation: Lessons from the United States. International Journal of Central Banking 13, 435-476.

Buch, C., Bussiere, M., Goldberg, L., Hills, R., 2018. International Transmission of Monetary Policy. National Bureau of Economic Research, Working Paper No. 24454.

Cetorelli, N., Goldberg, L., 2012. Banking globalization and monetary transmission. Journal of Finance 5, 1811-1843.

Committee on the Global Financial System, 2010. Funding patterns and liquidity management of internationally active banks. CGFS Paper No. 39.

Bremus, F., Fratzscher, M., 2015. Drivers of structural change in cross-border banking since the global financial crisis. Journal of International Money and Finance 52(C), 32-59.

Bruno, V., Shin, H.S., 2015. Capital flows and the risk-taking channel of monetary policy. Journal of Monetary Economics 71(C), 119-132.

Claus, E., Claus, I., Krippner, L., 2016. Asset markets and monetary policy shocks at the zero lower bound. Reserve Bank of New Zealand, Working Paper No. DP2014/03a.

Correa, R., Paligorova, T., Sapriza, H., Zlate, A., 2018. Cross-border bank flows and monetary policy. Unpublished manuscript.

Cortina, A., Fernández de Lis, S., 2016. El modelo de negocio de los bancos españoles en América Latina. BBVA Research, Working Paper No. 16/03.

de Haan, J., Oosterloo, S., Schoenmaker, D., 2015. Financial Markets and Institutions: A European Perspective (third edition). Cambridge University Press, Cambridge.

Dell'Ariccia, G., Laeven, L., Suarez, G., 2017. Bank leverage and monetary policy's risk-taking 
channel: Evidence from the United States. Journal of Finance 72(2), 613-654.

De Nederlandsche Bank, 2015. Perspective on the structure of the Dutch banking sector. Efficiency and stability through competition and diversity. DNB report, June.

den Haan, W. J., Sumner, S.W., Yamashiro, G.M., 2007. Bank loan portfolios and the monetary transmission mechanism. Journal of Monetary Economics 54(3), 904-924.

Drehmann, M., Borio, C., Tsatsaronis, K., 2011. Anchoring countercyclical capital buffers: the role of credit aggregates. BIS Working Papers No. 355.

Jimenez, G., Ongena, S., Pedro, J-L., Saurina, J. 2014. Hazardous times for monetary policy: What do twenty-three million bank loans say about the effects of monetary policy on credit risktaking?, Econometrica 82(2), 463-505.

Frost, J., Duijm, P., Bonner, C., de Haan, L. and de Haan, J. 2018. Cross-border effects of monetary policy and macroprudential capital regulation for Dutch banks, insurers and pension funds. DNB Working Paper, forthcoming.

Kashyap, A., Stein, J., 2000. What do a million observations on banks say about the transmission of monetary policy? American Economic Review 90, 407-428.

Krippner, L., 2013. Measuring the stance of monetary policy in zero lower bound environments. Economic Letters 118, 135-138.

McCauley, R., McGuire, P., von Peter, G., 2010. The architecture of global banking: From international to multinational? BIS Quarterly Review, March.

Morais, B., Peydro, J.L., Ruiz, C., 2018. The International Bank Lending Channel of Monetary Policy Rates and QE: Credit Supply, Reach-for-Yield, and Real Effects. Journal of Finance, forthcoming.

Paulson, A., Plestis, T., Rosen, R., McMenamin, R., Mohey-Deen, Z., 2014. Assessing the Vulnerability of the U.S. Life Insurance Industry, in: Biggs, J.H. and Richardson, M.P. (eds), Modernizing Insurance Regulation, John Wiley \& Sons, Inc., 61-83.

Rugman, Alan M., 2009. The Regional Multinationals: MNEs and 'Global' Strategic Management. Cambridge University Press, Cambridge.

Temesvary, J., Ongena, S., Owen, A., 2018. A global lending channel unplugged? Does U.S. 
monetary policy affect cross-border and affiliate lending by global U.S. banks? Journal of International Economics 112, 50-69.

van den Heuvel, S.J., 2002. Does bank capital matter for monetary transmission? Economic Policy Review, Federal Reserve Bank of New York, issue May, 259-265.

Venzin, M. 2009. Building an International Financial Services Firm. How Successful Firms Design and Execute Cross-Border Strategies. Oxford University Press, Oxford. 


\section{Table 1: Expected signs of coefficients in empirical specifications}

\begin{tabular}{|c|c|c|c|}
\hline & \multicolumn{2}{|c|}{ Dependent variable } & \multirow[t]{2}{*}{ Justification } \\
\hline & $\begin{array}{l}\text { Cross-border } \\
\text { claims }\end{array}$ & Local claims & \\
\hline $\begin{array}{l}\text { Direct effect of monetary } \\
\text { policy }\end{array}$ & Negative & Negative & $\begin{array}{l}\text { The effect on cross-border claims is } \\
\text { negative if the bank lending channel } \\
\text { applies. In contrast, the effect on } \\
\text { local claims will depend on whether } \\
\text { the local office is funded by the } \\
\text { parent or not (Morais et al., 2018). }\end{array}$ \\
\hline \multicolumn{4}{|l|}{ Conditional effect } \\
\hline \multicolumn{4}{|l|}{ Bank Lending Channel } \\
\hline Size (Total assets) & Positive & Positive & $\begin{array}{l}\text { Large (Kashyap and Stein,2000) } \\
\text { and global banks (Cetorelli and } \\
\text { Godberg, 2012) are not affected by } \\
\text { monetary policy changes. }\end{array}$ \\
\hline \multicolumn{4}{|l|}{ Portfolio Channel } \\
\hline $\begin{array}{l}\text { Capital ratio } \\
\end{array}$ & Ambiguous & Ambiguous & $\begin{array}{l}\text { According to the "bank capital } \\
\text { channel" (Van den Heuvel, 2002), } \\
\text { banks with lower capital } \\
\text { requirements reduce overall lending } \\
\text { after a monetary tightening. There } \\
\text { could also be some portfolio } \\
\text { rebalancing between foreign and } \\
\text { domestic claims for low-capitalized } \\
\text { banks following the bank-risk } \\
\text { taking channel (Jimenez et al, } \\
\text { 2014). It is not clear ex ante which } \\
\text { claims are riskier, thus the total } \\
\text { impact of a monetary policy } \\
\text { tightening on foreign claims is } \\
\text { ambiguous. }\end{array}$ \\
\hline
\end{tabular}

\section{Total effect}

Bank Lending Channel

Size (Total assets) No effect No Noffect $\quad$ No effect for banks with median size, but differentiated effects for banks in the upper and lower parts of the distributions for size.

Portfolio Channel

$$
\text { Capital ratio Ambiguous Ambiguous Overall effect will depend on }
$$
whether banks assess foreign claims as riskier than domestic claims when monetary policy tightens.

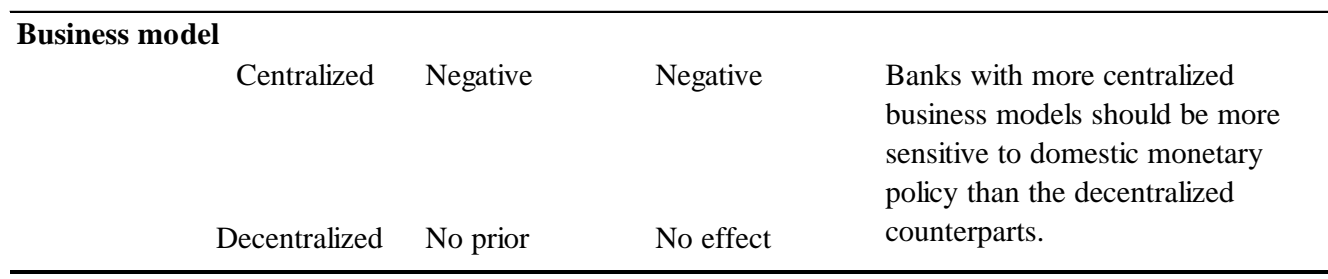


Table 2: Summary statistics

\begin{tabular}{|c|c|c|c|c|c|c|c|c|c|c|}
\hline \multirow[b]{2}{*}{ Country } & \multirow[b]{2}{*}{ Period covered } & \multirow[b]{2}{*}{$\begin{array}{l}\text { Number of Banks } \\
\text { (Total/Centralized } \\
\text { /Decentralized) or } \\
\text { Insurance } \\
\text { Companies or } \\
\text { Pension Funds } \\
\text { (Total) }\end{array}$} & \multirow[b]{2}{*}{$\begin{array}{l}\text { Number of } \\
\text { countries in } \\
\text { which } \\
\text { institutions } \\
\text { are active }\end{array}$} & \multicolumn{5}{|c|}{ Claims on private non-banks (1) } & \multicolumn{2}{|c|}{ Bank Characteristics } \\
\hline & & & & $\begin{array}{l}\text { Local } \\
\text { claims / } \\
\text { assets of } \\
\text { group (in } \\
\%)(2)\end{array}$ & $\begin{array}{l}\text { Cross- } \\
\text { border } \\
\text { claims / } \\
\text { assets of } \\
\text { group (in } \\
\%)\end{array}$ & $\begin{array}{l}\text { Log } \\
\text { change of } \\
\text { total } \\
\text { foreign } \\
\text { claims }\end{array}$ & $\begin{array}{l}\text { Log } \\
\text { change of } \\
\text { local } \\
\text { claims }\end{array}$ & $\begin{array}{l}\text { Log } \\
\text { change of } \\
\text { cross- } \\
\text { border } \\
\text { claims }\end{array}$ & $\begin{array}{l}\text { Log Total } \\
\text { Assets }\end{array}$ & $\begin{array}{c}\text { Tier } 1 \text { ratio } \\
\text { (in \%) (3) }\end{array}$ \\
\hline \multicolumn{11}{|l|}{ Mean Values } \\
\hline Netherlands. Banks & 2000Q1-2015Q4 & $20 / 16 / 4$ & 11 & 1.17 & 0.35 & 0.00 & 0.02 & 0.00 & 10.99 & 7.00 \\
\hline Spain. Banks & 2000Q1-2014Q4 & $18 / 15 / 2$ & 4 & 0.50 & 0.21 & 0.02 & 0.03 & 0.02 & 14.50 & 5.64 \\
\hline United States. Banks & 2000Q1-2015Q4 & $33 / 26 / 6$ & 16 & 0.10 & 0.15 & 0.00 & 0.004 & 0.00 & 26.04 & 11.67 \\
\hline Netherlands. Insurance Comp & 2006Q1-2015Q4 & 21 & 14 & 9.81 & - & -0.03 & - & - & 15.77 & 349.69 \\
\hline Netherlands. Pension Funds & 2006Q1-2015Q4 & 28 & 17 & 6.92 & - & -0.05 & - & - & 16.38 & 115.83 \\
\hline \multicolumn{11}{|l|}{ SD values } \\
\hline Netherlands. Banks & 2000Q1-2015Q4 & $2 / 2 / 1$ & 11 & 2.42 & 1.31 & 0.24 & 0.22 & 0.26 & 2.28 & 6.46 \\
\hline Spain. Banks & 2000Q1-2014Q4 & $4 / 4 / 1$ & 6 & 2.10 & 0.31 & 0.22 & 0.22 & 0.25 & 1.40 & 1.94 \\
\hline United States. Banks & 2000Q1-2015Q4 & $4 / 2 / 3$ & 14 & 0.50 & 0.60 & 0.27 & 0.29 & 0.28 & 1.98 & 3.38 \\
\hline Netherlands. Insurance Comp & 2006Q1-2015Q4 & 1 & 9 & 10.04 & - & 0.27 & - & - & 1.53 & 939.48 \\
\hline Netherlands. Pension Funds & 2006Q1-2015Q4 & 1 & 11 & 6.57 & - & 0.34 & - & - & 1.25 & 22.39 \\
\hline
\end{tabular}


Table 2: Summary statistics (cont.)

\begin{tabular}{|c|c|c|c|c|c|c|c|c|c|c|}
\hline \multirow[b]{2}{*}{ Country } & \multirow[b]{2}{*}{ Period covered } & \multirow[b]{2}{*}{$\begin{array}{l}\text { Number of Banks } \\
\text { (Total/Centralized } \\
\text { /Decentralized) or } \\
\text { Insurance } \\
\text { Companies and } \\
\text { Pension Funds } \\
\text { (Total) }\end{array}$} & \multirow[b]{2}{*}{$\begin{array}{l}\text { Number of } \\
\text { countries in } \\
\text { which Bank, } \\
\text { Insurance } \\
\text { Company, or } \\
\text { PensionFun } \\
\text { d is active }\end{array}$} & \multicolumn{5}{|c|}{ Claims on private non-banks (1) } & \multicolumn{2}{|c|}{ Bank Characteristics } \\
\hline & & & & $\begin{array}{l}\text { Local } \\
\text { claims by } \\
\text { affiliate / } \\
\text { total } \\
\text { assets of } \\
\text { group (in } \\
\%)(2)\end{array}$ & $\begin{array}{l}\text { Cross- } \\
\text { border } \\
\text { claims / } \\
\text { total } \\
\text { assets of } \\
\text { group (in } \\
\%)\end{array}$ & $\begin{array}{l}\text { Log } \\
\text { change of } \\
\text { total } \\
\text { foreign } \\
\text { claims }\end{array}$ & $\begin{array}{l}\text { Log } \\
\text { change of } \\
\text { local } \\
\text { claims by } \\
\text { bank } \\
\text { affiliates }\end{array}$ & $\begin{array}{l}\text { Log } \\
\text { change of } \\
\text { cross- } \\
\text { border } \\
\text { claims }\end{array}$ & $\begin{array}{l}\text { Log Total } \\
\text { Assets }\end{array}$ & $\begin{array}{c}\text { Tier } 1 \text { ratio } \\
\text { (in \%) (3) }\end{array}$ \\
\hline \multicolumn{11}{|l|}{ Min values } \\
\hline Netherlands. Banks & 2000Q1-2015Q4 & $16 / 12 / 1$ & 0 & 0.00 & 0.00 & -1.00 & -1.00 & -1.00 & 3.18 & 0.76 \\
\hline Spain. Banks & 2000Q1-2014Q4 & $11 / 8 / 2$ & 1 & 0.00 & 0.00 & -0.98 & -0.96 & -0.98 & 11.04 & 0.25 \\
\hline United States. Banks & 2000Q1-2015Q4 & $26 / 22 / 3$ & 1 & 0.00 & 0.00 & -1.00 & -1.00 & -1.00 & 19.68 & 3.88 \\
\hline Netherlands. Insurance Comp & 2006Q1-2015Q4 & 19 & 0 & 0.04 & - & -1.00 & - & - & 12.75 & 100.92 \\
\hline Netherlands. Pension Funds & 2006Q1-2015Q4 & 26 & 0 & 0.00 & - & -1.00 & - & - & 13.67 & 0.00 \\
\hline \multicolumn{11}{|l|}{ Max values } \\
\hline Netherlands. Banks & 2000Q1-2015Q4 & $23 / 19 / 4$ & 37 & 19.76 & 26.25 & 0.99 & 0.98 & 0.99 & 13.90 & 36.47 \\
\hline Spain. Banks & 2000Q1-2014Q4 & $25 / 25 / 3$ & 24 & 22.18 & 2.39 & 0.96 & 0.98 & 0.98 & 16.38 & 21.91 \\
\hline United States. Banks & 2000Q1-2015Q4 & $39 / 30 / 12$ & 48 & 11.22 & 19.27 & 1.00 & 1.00 & 1.00 & 28.51 & 36.39 \\
\hline Netherlands. Insurance Comp & 2006Q1-2015Q4 & 22 & 36 & 74.9 & - & 1.00 & - & - & 18.36 & 2452.88 \\
\hline Netherlands. Pension Funds & 2006Q1-2015Q4 & 29 & 39 & 57.77 & - & 1.00 & - & - & 19.74 & 252.70 \\
\hline
\end{tabular}

(1) Claims to total private sector for insurance companies and pension funds; (2) Total Private foreign claims for insurance companies and pension funds; (3) Solvency ratio for insurance companies and pension funds. 


\section{Table 3: Foreign activities and the bank lending channel}

The results reported correspond to the estimates of equation (1) using size (log of total assets) as the friction or conditional effect. The dependent variable is the log change in cross-border claims to foreign residents in the non-bank private sector in columns (1)-(3) and the log change in local claims in columns (4)-(6). The Direct effect is the annual cumulative effect of the change in the domestic policy rate, while the Conditional effect captures the interaction between the policy rate and the proxy for bank size. The sum of these two sets of coefficients are reported in the row for the Total effect, and are evaluated at the $25^{\text {th }}, 50^{\text {th }}$, and $75^{\text {th }}$ percentiles of the distribution for the bank size proxy. The data are quarterly from 2000Q1 to 2015Q4 for a panel of Dutch and U.S. domestically-owned banks with foreign exposures and from 2000Q1 to 2014Q4 for domestically-owned Spanish banks. All specifications include a set of bank, home country, counterparty country, and global (VIX) controls, as well as bank and counterparty country fixed effects. The full results of this specifications are reported in Table OA1 and OA2 of the online appendix. Standard errors are clustered by bank and p-values are shown in brackets. ***, **, and * indicate significance at the $1 \%, 5 \%$, and $10 \%$ level, respectively.

\begin{tabular}{|c|c|c|c|c|c|c|c|c|c|c|c|c|c|c|c|c|c|c|}
\hline \multicolumn{19}{|c|}{ Conditional effect: Size } \\
\hline & \multicolumn{9}{|c|}{ Cross-border claims } & \multicolumn{9}{|c|}{ Local Claims } \\
\hline & \multicolumn{3}{|c|}{ (1) } & \multicolumn{3}{|c|}{$(2)$} & \multicolumn{3}{|c|}{ (3) } & \multicolumn{3}{|c|}{ (4) } & \multicolumn{3}{|c|}{ (5) } & \multicolumn{3}{|c|}{ (6) } \\
\hline & \multicolumn{3}{|c|}{ Netherlands } & \multicolumn{3}{|c|}{ Spain } & \multicolumn{3}{|c|}{ United States } & \multicolumn{3}{|c|}{ Netherlands } & \multicolumn{3}{|c|}{ Spain } & \multicolumn{3}{|c|}{ United States } \\
\hline Direct effect & \multicolumn{3}{|c|}{$\begin{array}{c}-0.216^{* *} \\
{[0.014]}\end{array}$} & \multicolumn{3}{|c|}{$\begin{array}{c}-0.411 * * * \\
{[0.000]}\end{array}$} & \multicolumn{3}{|c|}{$\begin{array}{c}-0.194 \\
{[0.116]}\end{array}$} & \multicolumn{3}{|c|}{$\begin{array}{l}-0.012 \\
{[0.912]}\end{array}$} & \multicolumn{3}{|c|}{$\begin{array}{c}0.051 \\
{[0.849]}\end{array}$} & \multicolumn{3}{|c|}{$\begin{array}{l}-0.205 \\
{[0.233]}\end{array}$} \\
\hline Cond. effect & \multicolumn{3}{|c|}{$\begin{array}{c}0.022 * * * \\
{[0.004]}\end{array}$} & \multicolumn{3}{|c|}{$\begin{array}{c}0.033^{* * * *} \\
{[0.000]}\end{array}$} & \multicolumn{3}{|c|}{$\begin{array}{l}0.009 * \\
{[0.069]}\end{array}$} & \multicolumn{3}{|c|}{$\begin{array}{c}0.008 \\
{[0.357]}\end{array}$} & \multicolumn{3}{|c|}{$\begin{array}{c}0.002 \\
{[0.889]}\end{array}$} & \multicolumn{3}{|c|}{$\begin{array}{c}0.010 \\
{[0.121]}\end{array}$} \\
\hline \begin{tabular}{|l|} 
Total effect \\
(25/50/75 pctls)
\end{tabular} & $\begin{array}{l}-0.066 \\
{[0.102]}\end{array}$ & \begin{tabular}{|c|}
-0.021 \\
{$[0.478]$}
\end{tabular} & $\begin{array}{c}0.007 \\
{[0.762]}\end{array}$ & $\begin{array}{c}-0.033 \\
{[0.280]}\end{array}$ & $\begin{array}{l}-0.011 \\
{[0.698]}\end{array}$ & $\begin{array}{c}0.022 \\
{[0.366]}\end{array}$ & $\begin{array}{c}0.025^{* * *} \\
{[0.002]}\end{array}$ & $\begin{array}{c}0.032^{* * *} \\
{[0.000]}\end{array}$ & {$\left[\begin{array}{c}0.045^{* * *} \\
{[0.000]}\end{array}\right.$} & $\begin{array}{c}0.044 \\
{[0.394]}\end{array}$ & $\begin{array}{c}0.060 \\
{[0.128]}\end{array}$ & $\begin{array}{l}0.071^{* *} \\
{[0.045]}\end{array}$ & $\begin{array}{c}0.079 \\
{[0.221]}\end{array}$ & $\begin{array}{c}0.081 \\
{[0.131]}\end{array}$ & $\begin{array}{l}0.084^{* *} \\
{[0.028]}\end{array}$ & $\begin{array}{c}0.043^{* * *} \\
{[0.006]}\end{array}$ & $* \begin{array}{c}0.051^{* * *} \\
{[0.000]}\end{array}$ & {$\left[\begin{array}{c}0.066^{* * *} \\
{[0.000]}\end{array}\right.$} \\
\hline Observations & \multicolumn{3}{|c|}{9,133} & \multicolumn{3}{|c|}{3,772} & \multicolumn{3}{|c|}{23,825} & \multicolumn{3}{|c|}{2,596} & \multicolumn{3}{|c|}{1,578} & \multicolumn{3}{|c|}{9,776} \\
\hline R-squared & \multicolumn{3}{|c|}{0.017} & \multicolumn{3}{|c|}{0.032} & & 0.009 & & & 0.025 & & & 0.075 & & & 0.019 & \\
\hline Adjusted R-squared & & 0.009 & & & 0.014 & & & 0.004 & & & 0.006 & & & 0.042 & & & 0.010 & \\
\hline
\end{tabular}




\section{Table 4: Foreign activities and the portfolio channel}

The results reported correspond to the estimates of equation (1) using bank capital (the Tier 1 Leverage ratio) as the friction or conditional effect. The dependent variable is the log change in cross-border claims to foreign residents in the non-bank private sector in columns (1)-(3) and the log change in local claims in columns (4)-(6). The Direct effect is the annual cumulative effect of the change in the domestic shadow rate, while the Conditional effect captures the interaction between the policy rate and the proxy for bank capital. The sum of these two sets of coefficients are reported in the row for the Total effect, and are evaluated at the $25^{\text {th }}, 50^{\text {th }}$, and $75^{\text {th }}$ percentiles of the distribution for the bank capital proxy. The data are quarterly from 2000Q1 to 2015Q4 for a panel of Dutch and U.S.

domestically-owned banks with foreign exposures and from 2000Q1 to 2014Q4 for domestically-owned Spanish banks. All specifications include a set of bank, home country, counterparty country, and global (VIX) controls, as well as bank and counterparty country fixed effects. The full results of this specifications are reported in Table OA3 and OA4 of the online appendix. Standard errors are clustered by bank and p-values are shown in brackets. $* * *, * *$, and $*$ indicate significance at the $1 \%, 5 \%$, and $10 \%$ level, respectively.

\begin{tabular}{|c|c|c|c|c|c|c|c|c|c|c|c|c|c|c|c|c|c|c|}
\hline \multicolumn{19}{|c|}{ Conditional effect: Capital } \\
\hline & \multicolumn{9}{|c|}{ Cross-border claims } & \multicolumn{9}{|c|}{ Local Claims } \\
\hline & \multicolumn{3}{|c|}{$(1)$} & \multicolumn{3}{|c|}{$(2)$} & \multicolumn{3}{|c|}{ (3) } & \multicolumn{3}{|c|}{$(4)$} & \multicolumn{3}{|c|}{ (5) } & \multicolumn{3}{|c|}{$(6)$} \\
\hline & \multicolumn{3}{|c|}{ Netherlands } & \multicolumn{3}{|c|}{ Spain } & \multicolumn{3}{|c|}{ United States } & \multicolumn{3}{|c|}{ Netherlands } & \multicolumn{3}{|c|}{ Spain } & \multicolumn{3}{|c|}{ United States } \\
\hline Direct effect & \multicolumn{3}{|c|}{$\begin{array}{c}0.024 \\
{[0.212]} \\
\end{array}$} & \multicolumn{3}{|c|}{$\begin{array}{c}0.028 \\
{[0.370]}\end{array}$} & \multicolumn{3}{|c|}{$\begin{array}{c}0.045^{* *} \\
{[0.031]} \\
\end{array}$} & \multicolumn{3}{|c|}{$\begin{array}{c}0.061 \\
{[0.190]}\end{array}$} & \multicolumn{3}{|c|}{$\begin{array}{c}0.008 \\
{[0.864]}\end{array}$} & \multicolumn{3}{|c|}{$\begin{array}{c}0.083^{* * *} \\
{[0.001]}\end{array}$} \\
\hline Cond. effect & \multicolumn{3}{|c|}{$\begin{array}{c}-0.005^{* *} \\
{[0.034]}\end{array}$} & \multicolumn{3}{|c|}{$\begin{array}{l}-0.001 \\
{[0.766]} \\
\end{array}$} & \multicolumn{3}{|c|}{$\begin{array}{l}-0.005^{*} \\
{[0.058]} \\
\end{array}$} & \multicolumn{3}{|c|}{$\begin{array}{c}0.001 \\
{[0.846]}\end{array}$} & \multicolumn{3}{|c|}{$\begin{array}{c}0.002 \\
{[0.860]} \\
\end{array}$} & \multicolumn{3}{|c|}{$\begin{array}{c}-0.008^{* * *} \\
{[0.003]}\end{array}$} \\
\hline Total effect & 0.010 & 0.000 & -0.012 & 0.022 & 0.021 & 0.020 & -0.001 & -0.016 & -0.028 & 0.040 & 0.026 & 0.008 & 0.015 & 0.017 & 0.019 & 0.012 & -0.012 & -0.030 \\
\hline (25/50//J petus) & {$[0.563]$} & [0.999] & [0.403] & {$[0.258]$} & {$[0.267]$} & [0.313] & {$[0.926]$} & {$[0.217]$} & [0.143] & {$[0.186]$} & {$[0.221]$} & {$[0.650]$} & [0.317] & [0.253] & [0.367] & {$[0.273]$} & {$[0.405]$} & [0.124] \\
\hline Observations & \multicolumn{3}{|c|}{9,133} & \multicolumn{3}{|c|}{3,772} & \multicolumn{3}{|c|}{23,951} & \multicolumn{3}{|c|}{2,596} & \multicolumn{3}{|c|}{1,578} & \multicolumn{3}{|c|}{9,815} \\
\hline R-squared & \multicolumn{3}{|c|}{0.018} & & 0.029 & & & 0.010 & & & 0.025 & & & 0.067 & & & 0.020 & \\
\hline $\begin{array}{l}\text { Adjusted R- } \\
\text { squared }\end{array}$ & & 0.009 & & & 0.010 & & & 0.004 & & & 0.006 & & & 0.033 & & & 0.010 & \\
\hline
\end{tabular}




\section{Table 5: Foreign activities and banks’ business models}

The results reported correspond to the estimates of equation (2) using a Decentralization dummy (equal to 1 if a bank has a ratio of local claims over total foreign claims greater than $50 \%$ ) as the business model proxy. The dependent variable is the log change in total claims to foreign residents in the non-bank private sector in columns (1)-(3), the log change in local claims in columns (4)-(6), and the log change in cross-border claim in columns (7)-(9). The Direct effect is the annual cumulative effect of the change in the domestic shadow rate, while the Decentralizaton effect captures the interaction between the policy rate and the

Decentralization dummy. The sum of these two sets of coefficients are reported in the row for the Total effect. The data are quarterly from $2000 \mathrm{Q} 1$ to $2015 \mathrm{Q} 4$ for a panel of Dutch and U.S. domestically-owned banks with foreign exposures and from 2000Q1 to 2014Q4 for domestically-owned Spanish banks. All specifications include a set of bank, home country, counterparty country, and global (VIX) controls, as well as bank and counterparty country fixed effects. The full results of this specifications are reported in Table OA5 of the online appendix. Standard errors are clustered by bank and p-values are shown in brackets. ***, $* *$, and * indicate significance at the $1 \%, 5 \%$, and $10 \%$ level, respectively.

\begin{tabular}{|c|c|c|c|c|c|c|c|c|c|}
\hline & \multicolumn{9}{|c|}{ Dependent Variable } \\
\hline & \multicolumn{3}{|c|}{ Total claims } & \multicolumn{3}{|c|}{ Local claims } & \multicolumn{3}{|c|}{ Cross-border claims } \\
\hline & $(1)$ & $(2)$ & (3) & (4) & (5) & $(6)$ & $(7)$ & (8) & (9) \\
\hline & $\mathrm{NL}$ & $\mathrm{SP}$ & U.S. & $\mathrm{NL}$ & SP & U.S. & NL & $\mathrm{SP}$ & U.S. \\
\hline Direct effect & $\begin{array}{c}-0.001 \\
{[0.966]}\end{array}$ & $\begin{array}{r}0.0329 \\
(0.294) \\
\end{array}$ & $\begin{array}{c}0.033 * * * \\
{[0.001]}\end{array}$ & $\begin{array}{c}0.117 \\
{[0.410]} \\
\end{array}$ & $\begin{array}{r}0.0749 \\
(0.109) \\
\end{array}$ & $\begin{array}{c}0.061^{* * * *} \\
{[0.000]}\end{array}$ & $\begin{array}{r}-0.013 \\
{[0.635]} \\
\end{array}$ & $\begin{array}{c}0.00333 \\
(0.903) \\
\end{array}$ & $\begin{array}{c}0.029 * * * \\
{[0.006]}\end{array}$ \\
\hline Decentralization effect & $\begin{array}{c}0.0787 \\
{[0.205]}\end{array}$ & $\begin{array}{c}0.053^{* * *} \\
{[0.007]}\end{array}$ & $\begin{array}{c}0.008 \\
{[0.652]}\end{array}$ & $\begin{array}{c}0.331^{*} \\
{[0.063]}\end{array}$ & $\begin{array}{c}0.013 \\
{[0.794]} \\
\end{array}$ & $\begin{array}{c}-0.001 \\
{[0.895]}\end{array}$ & $\begin{array}{c}0.111 \\
{[0.114]}\end{array}$ & $\begin{array}{c}0.107 * * * \\
{[0.000]}\end{array}$ & $\begin{array}{c}0.018 \\
{[0.368]}\end{array}$ \\
\hline Total effect (decentralized bank) & $\begin{array}{c}0.078 \\
{[0.189]}\end{array}$ & $\begin{array}{c}0.086^{*} \\
{[0.000]}\end{array}$ & $\begin{array}{c}0.041 * * \\
{[0.012]}\end{array}$ & $\begin{array}{c}0.448 \\
{[0.187]}\end{array}$ & $\begin{array}{c}0.088 * * * \\
{[0.000]}\end{array}$ & $\begin{array}{c}0.060 * * * \\
{[0.000]}\end{array}$ & $\begin{array}{c}0.098 * \\
{[0.090]}\end{array}$ & $\begin{array}{c}0.110^{* * * *} \\
{[0.000]}\end{array}$ & $\begin{array}{c}0.047 * * * \\
{[0.008]}\end{array}$ \\
\hline Observations & 9,823 & 3,830 & 25,029 & 2,609 & 1,580 & 9,776 & 9,178 & 3,795 & 23,825 \\
\hline R-squared & 0.018 & 0.042 & 0.010 & 0.027 & 0.071 & 0.019 & 0.017 & 0.033 & 0.009 \\
\hline Adjusted R-squared & 0.010 & 0.024 & 0.005 & 0.008 & 0.037 & 0.010 & 0.008 & 0.015 & 0.004 \\
\hline
\end{tabular}


Figure 1: Degree of banks’ (de)centralization

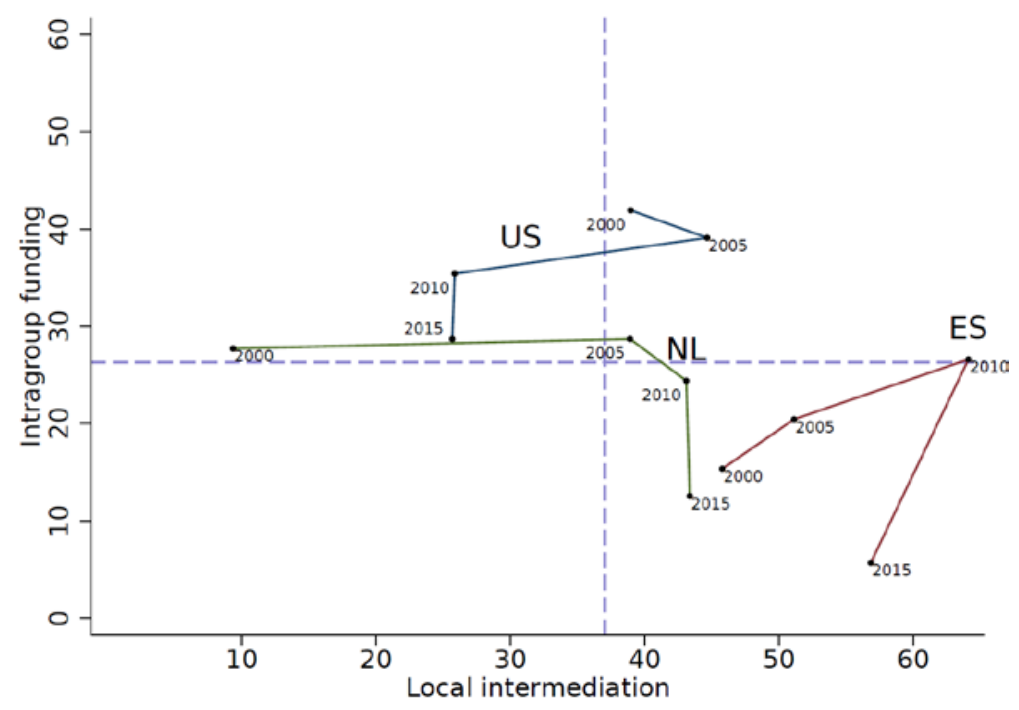

Note: Intragroup funding is the share of total foreign intragroup liabilities to total liabilities. A higher score indicates a more centralized country. Local intermediation is the minima of local assets and local liabilities for each counterparty country summed over all counterparties and then divided by total foreign claims. A higher score indicates a less centralized country. The vertical and horizontal dashed lines represent the $75^{\text {th }}$ percentile of the historical (since 2000) distribution of the respective variables. The data for this figure are from the BIS International Banking Statistics.

Figure 2: Banks' international exposures

\section{Panel A - Netherlands}

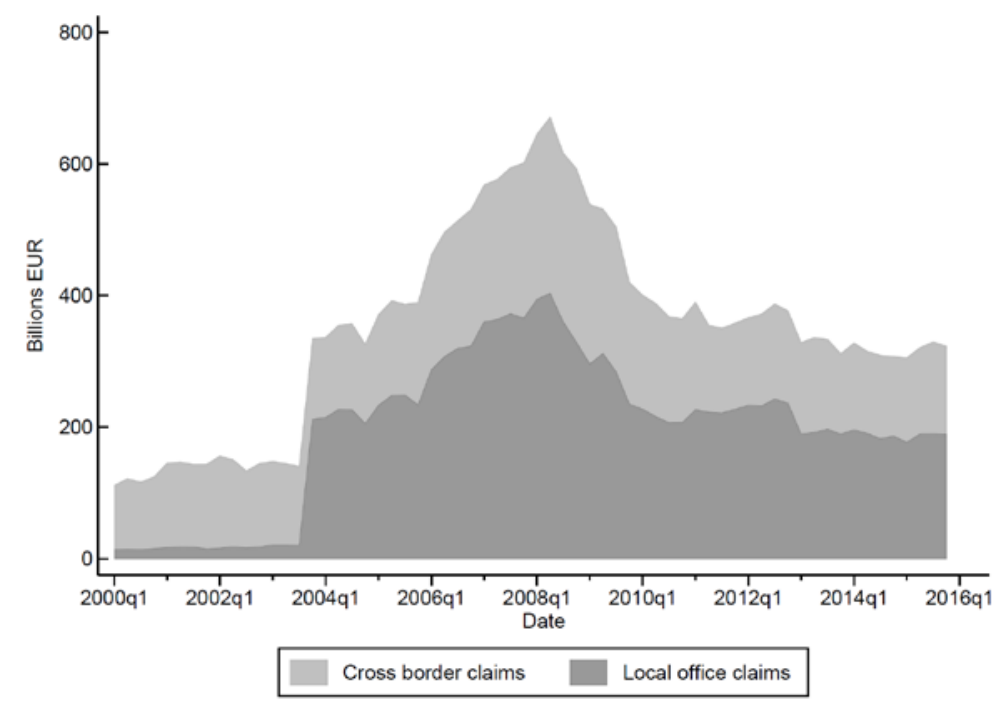




\section{Panel B - Spain}

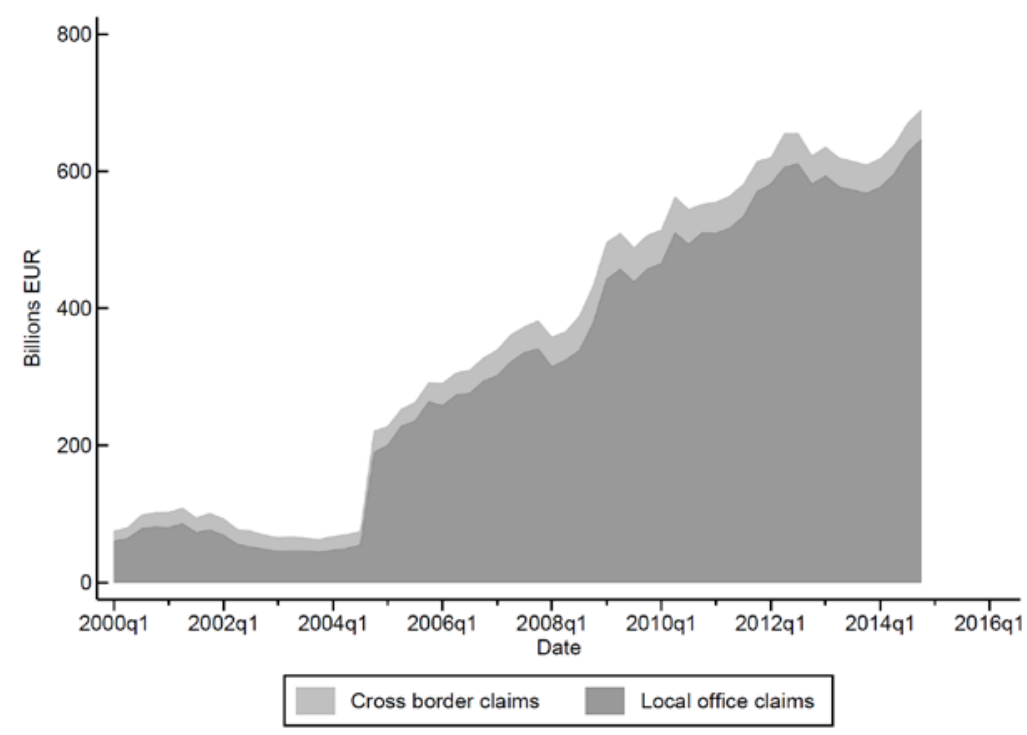

Panel C - United States

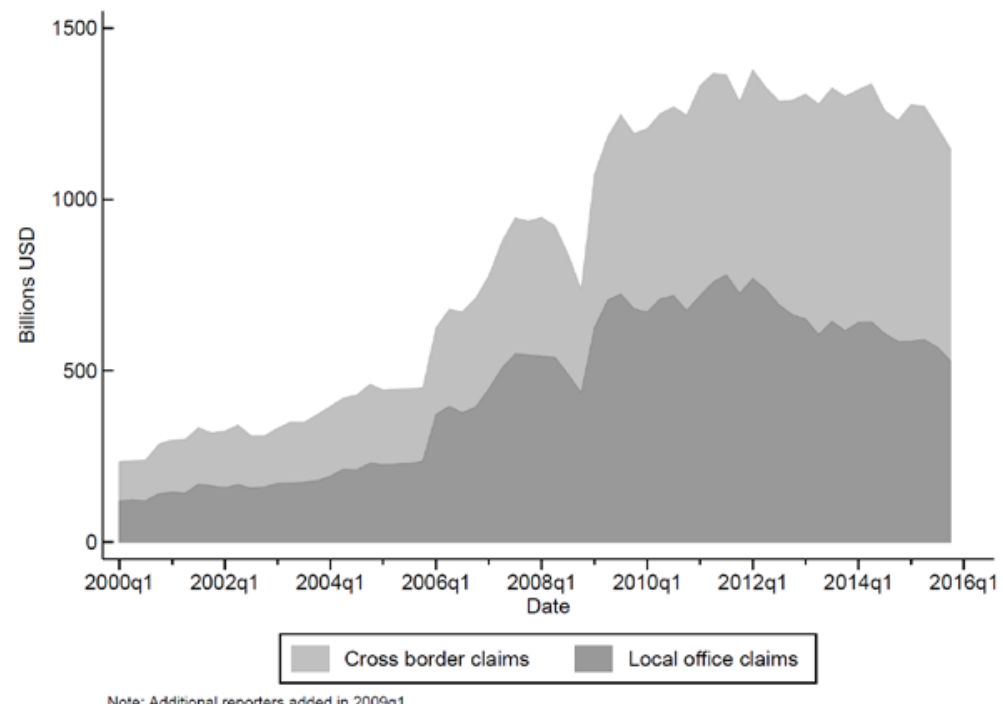


Figure 3: Foreign claims of Dutch insurance companies and pension funds

Panel A - Insurance companies

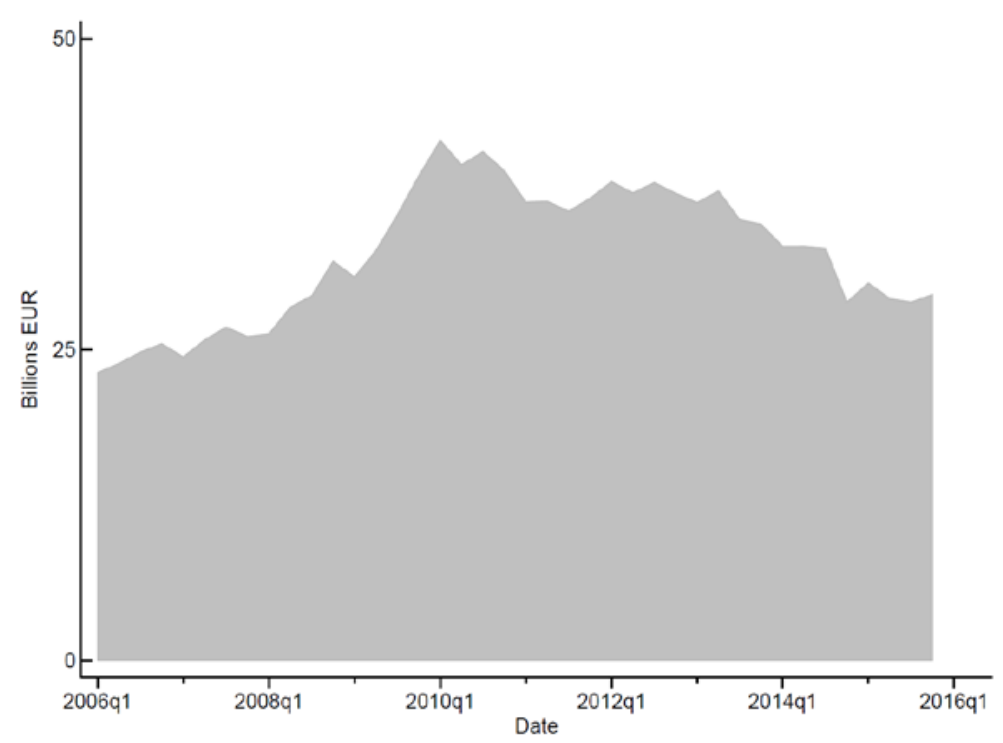

Panel B - Pension funds

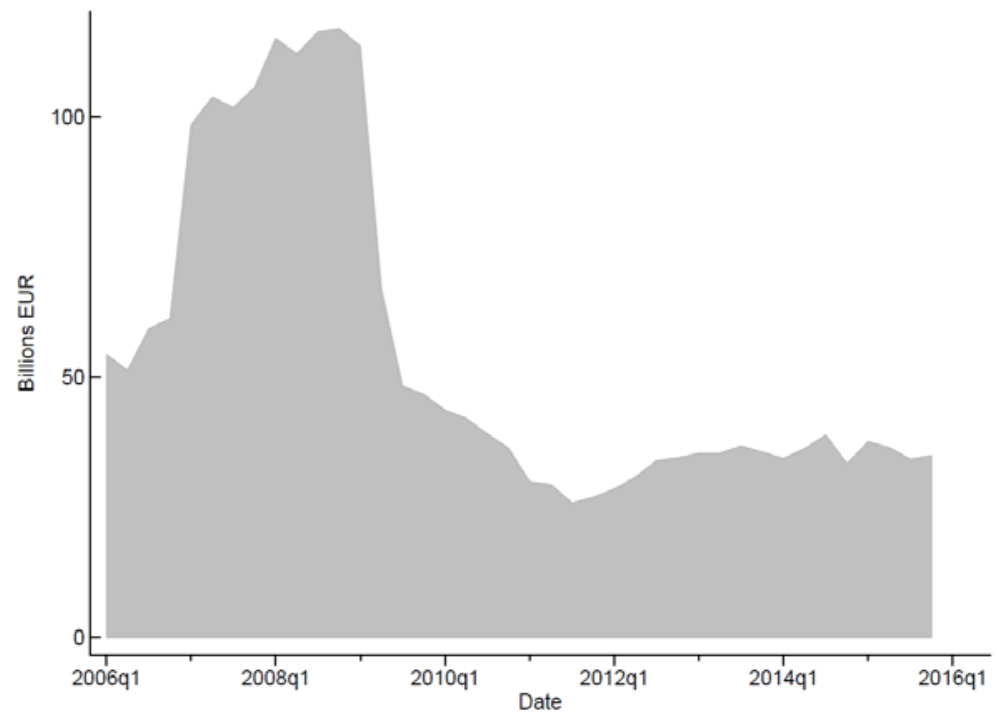




\section{Appendix}

Table A1: Netherlands Variable Definitions

\begin{tabular}{|c|c|}
\hline Variable & Description \\
\hline \multicolumn{2}{|l|}{ Dependent variables } \\
\hline Log changes in foreign claims on all sectors & $\begin{array}{l}\text { Quarterly difference in natural log of foreign claims on all } \\
\text { sectors, in EUR million }\end{array}$ \\
\hline Log changes in foreign claims on private sector & $\begin{array}{l}\text { Quarterly difference in natural log of foreign claims on private } \\
\text { sector borrowers, in EUR million }\end{array}$ \\
\hline \multicolumn{2}{|l|}{ Independent variables (in pp) } \\
\hline Short Term (Wholesale) Funding Ratio & All non-deposit funding over total assets \\
\hline Liquid Asset Ratio & Cash and deposits in central banks over total assets \\
\hline Log Total Assets & Natural log of total assets \\
\hline Tier 1 ratio & Tier 1 equity capital over total assets \\
\hline C\&I Loans / Total Assets & Not available \\
\hline Securities / Total Assets & Not available \\
\hline Total Claims on Foreign Borrowers / Total Assets & $\begin{array}{l}\text { Local plus cross-border claims on foreign borrowers (all } \\
\text { sectors) over total assets }\end{array}$ \\
\hline Core deposits ratio & Core deposits over total assets \\
\hline
\end{tabular}

Source: DNB country risk reporting, CoRep

Table A2: Spain Variable Definitions

\begin{tabular}{|c|c|}
\hline Variable & Description \\
\hline \multicolumn{2}{|l|}{ Dependent variable } \\
\hline Log changes in foreign claims on all sectors & $\begin{array}{l}\text { Quarterly difference in natural log of foreign claims on all } \\
\text { sectors exchange-rate adjusted, in } € \text { million }\end{array}$ \\
\hline Log changes in foreign claims on private sector & $\begin{array}{l}\text { Quarterly difference in natural log of foreign claims on private } \\
\text { non-bank sector borrowers exchange rate adjusted, in } € \text { million }\end{array}$ \\
\hline \multicolumn{2}{|l|}{ Independent variables (in pp) } \\
\hline Short Term (Wholesale) Funding Ratio & All non-deposit funding over total liabilities \\
\hline Liquid Asset Ratio & Cash and deposits in central banks over total assets \\
\hline Log Total Assets & Natural log of real total assets (in $€$ millions) \\
\hline Tier 1 ratio & Own funds over total assets \\
\hline C\&I Loans / Total Assets & Total loans to private non-financial sector over total assets \\
\hline Securities / Total Assets & $\begin{array}{l}\text { Sum of gross debt and other capital instruments over total } \\
\text { assets }\end{array}$ \\
\hline Total Claims on Foreign Borrowers / Total Assets & Total foreign financial assets over total assets \\
\hline Core deposits ratio & Client deposits over total liabilities \\
\hline
\end{tabular}

Source: Confidential bank balance sheet reports 
Table A3: United States Variable Definitions

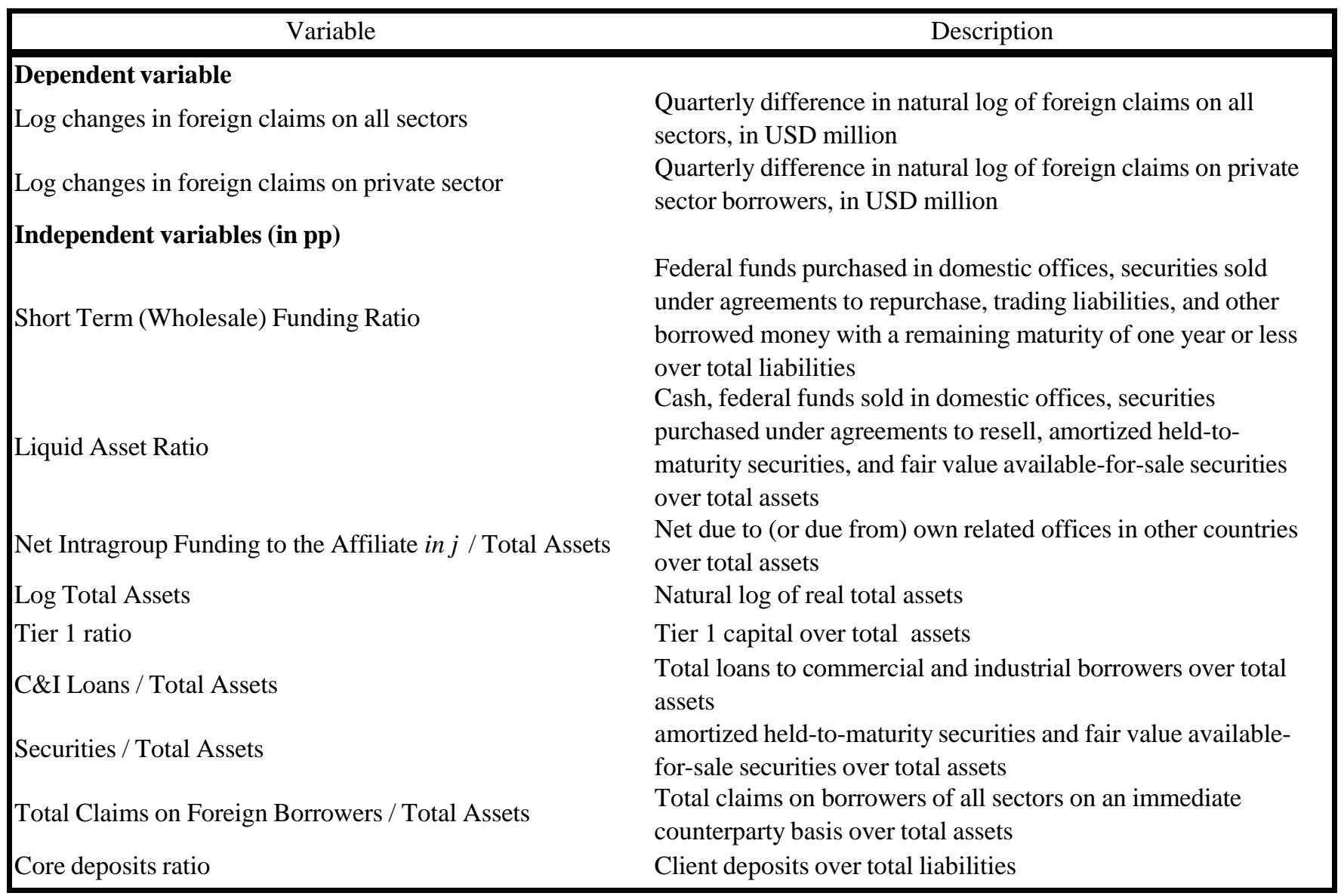

Source: Federal Financial Institutions Examinations Council (FFIEC) 031 form (“Call Report”); FR Y-9C form; FFIEC 009 report

Table A4: Netherlands Insurance Companies and Pension Funds Variable Definitions

\begin{tabular}{|ll|}
\hline \multicolumn{1}{|c|}{ Variable } & \multicolumn{1}{c|}{ Description } \\
\hline Dependent variable & $\begin{array}{l}\text { Quarterly difference in natural log of foreign claims on all } \\
\text { sectors, in EUR million } \\
\text { Quarterly difference in natural log of foreign claims on non- } \\
\text { financial companies, insurance companies, pension funds, other } \\
\text { financial institutions, households, in EUR million }\end{array}$ \\
Log changes in private claims & $\begin{array}{l}\text { Cash over total assets } \\
\text { Independent variables (in pp) }\end{array}$ \\
Liquid Asset Ratio & $\begin{array}{l}\text { Natural log of total assets } \\
\text { Total own funds over solvency requirements }\end{array}$ \\
Solvency ratio & Total foreign claims/total assets \\
International activities ratio & Tssets
\end{tabular}

Source: DNB balance of payment statistics 